\title{
Laser vision: lidar as a transformative tool to advance critical zone science
}

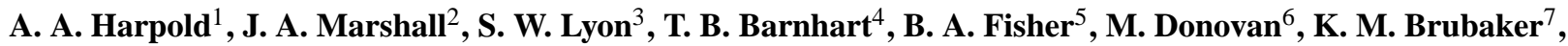 \\ C. J. Crosby ${ }^{8}$, N. F. Glenn ${ }^{9}$, C. L. Glennie ${ }^{10}$, P. B. Kirchner ${ }^{11}$, N. Lam $^{3}$, K. D. Mankoff ${ }^{12}$, J. L. McCreight ${ }^{13}$, \\ N. P. Molotch ${ }^{4}$, K. N. Musselman ${ }^{14}$, J. Pelletier ${ }^{15}$, T. Russo ${ }^{16}$, H. Sangireddy ${ }^{17}$, Y. Sjöberg ${ }^{3}$, T. Swetnam ${ }^{15}$, and \\ N. West $^{16}$ \\ ${ }^{1}$ University of Nevada, Department of Natural Resources and Environmental Science, Reno, Nevada, USA \\ ${ }^{2}$ University of Oregon, Department of Geological Sciences, Eugene, Oregon, USA \\ ${ }^{3}$ Stockholm University, Department of Physical Geography, Stockholm, Sweden \\ ${ }^{4}$ University of Colorado, Geography Department and Institute for Arctic and Alpine Research, Boulder, Colorado, USA \\ ${ }^{5}$ University of Minnesota, Land and Atmospheric Science, Minnesota, St. Paul, Minnesota,USA \\ ${ }^{6}$ University of Maryland, Geography and Environmental Systems Department, Baltimore County, Baltimore, Maryland, USA \\ ${ }^{7}$ Hobart and William Smith Colleges, Environmental Studies, Geneva, New York, USA \\ ${ }^{8}$ UNAVCO, Boulder, Colorado, USA \\ ${ }^{9}$ Boise State University, Department of Geosciences, Boise, Idaho, USA \\ ${ }^{10}$ University of Houston, Department of Civil and Environmental Engineering, Houston, Texas, USA \\ ${ }^{11}$ University of California, Joint Institute for Regional Earth System Science and Engineering, Los Angeles, California, USA \\ ${ }^{12}$ Woods Hole Oceanographic Institute, Department of Physical Oceanography, Woods Hole, Massachusetts, USA \\ ${ }^{13}$ National Center for Atmospheric Research, Boulder, Colorado, USA \\ ${ }^{14}$ University of Saskatchewan, Centre for Hydrology, Saskatchewan, Canada \\ ${ }^{15}$ University of Arizona, Department of Geosciences, Tucson, Arizona, USA \\ ${ }^{16}$ Pennsylvania State University, State College, Department of Geosciences, Pennsylvania, USA \\ ${ }^{17}$ University of Texas, Department of Civil Engineering, Austin, Texas, USA
}

Correspondence to: A. A. Harpold (aharpold@ cabnr.unr.edu)

Received: 04 December 2014 - Published in Hydrol. Earth Syst. Sci. Discuss.: 23 January 2015

Revised: 01 May 2015 - Accepted: 21 May 2015 - Published: 22 June 2015

\begin{abstract}
Observation and quantification of the Earth's surface is undergoing a revolutionary change due to the increased spatial resolution and extent afforded by light detection and ranging (lidar) technology. As a consequence, lidar-derived information has led to fundamental discoveries within the individual disciplines of geomorphology, hydrology, and ecology. These disciplines form the cornerstones of critical zone (CZ) science, where researchers study how interactions among the geosphere, hydrosphere, and biosphere shape and maintain the "zone of life", which extends from the top of unweathered bedrock to the top of the vegetation canopy. Fundamental to $\mathrm{CZ}$ science is the development of transdisciplinary theories and tools that transcend disciplines and inform other's work, capture new levels of com-
\end{abstract}

plexity, and create new intellectual outcomes and spaces. Researchers are just beginning to use lidar data sets to answer synergistic, transdisciplinary questions in $\mathrm{CZ}$ science, such as how $\mathrm{CZ}$ processes co-evolve over long timescales and interact over shorter timescales to create thresholds, shifts in states and fluxes of water, energy, and carbon. The objective of this review is to elucidate the transformative potential of lidar for CZ science to simultaneously allow for quantification of topographic, vegetative, and hydrological processes. A review of 147 peer-reviewed lidar studies highlights a lack of lidar applications for $\mathrm{CZ}$ studies as $38 \%$ of the studies were focused in geomorphology, $18 \%$ in hydrology, $32 \%$ in ecology, and the remaining $12 \%$ had an interdisciplinary focus. A handful of exemplar transdisciplinary studies demon- 
strate lidar data sets that are well-integrated with other observations can lead to fundamental advances in $\mathrm{CZ}$ science, such as identification of feedbacks between hydrological and ecological processes over hillslope scales and the synergistic co-evolution of landscape-scale CZ structure due to interactions amongst carbon, energy, and water cycles. We propose that using lidar to its full potential will require numerous advances, including new and more powerful open-source processing tools, exploiting new lidar acquisition technologies, and improved integration with physically based models and complementary in situ and remote-sensing observations. We provide a 5-year vision that advocates for the expanded use of lidar data sets and highlights subsequent potential to advance the state of $\mathrm{CZ}$ science.

\section{Introduction}

Complex interactions among the geosphere, ecosphere, and hydrosphere give rise to present-day landforms, vegetation, and corresponding water and energy fluxes. Critical zone (CZ) science studies these interactions in the zone extending from the top of unweathered bedrock to the top of the vegetation canopy. Understanding $\mathrm{CZ}$ function is fundamental for characterizing regolith formation, carbon-energy-water cycles, meteorological controls on ecology, linked surface and subsurface processes, and numerous other Earth surface processes (NRC, 2012). Improved understanding of CZ functions is thus important for quantifying ecosystem services and predicting their sensitivity to environmental change. However, $\mathrm{CZ}$ processes are difficult to observe because they occur over timescales of seconds to eons and spatial scales of centimeters to kilometers, and thus require diverse measurement approaches (Chorover et al., 2011). Light detection and ranging (lidar) technologies can be helpful in this regard because they generate repeatable, precise three-dimensional information of the Earth's surface characteristics.

Lidar allows for simultaneous measurements of aboveground vegetation structure and human infrastructure, as well as the topography of the Earth surface, including soils, exposed bedrock, stream channels, and snow/ice. Depending on the data collection system and platform, observations can be made at the landscape scale $\left(>1000 \mathrm{~km}^{2}\right)$ and at spatial resolutions capable of capturing fine-scale processes $(<10 \mathrm{~cm})$. These unique measurement capabilities offered by lidar have the potential to help answer transdisciplinary research questions, which transcend a single discipline, capture greater complexity, and create new intellectual advances that are synergistic (across disciplines) in nature. Fundamental CZ science questions often require transdisciplinary approaches that surpass what is possible in multidisciplinary (i.e., collaborations across disciplines that pose their own questions) or interdisciplinary (i.e., collaborations where information is transferred amongst disciplines) research set- tings. Because lidar can characterize geomorphic, ecologic, and hydrologic processes simultaneously across a range of scales, it is uniquely suited to address questions posed by $\mathrm{CZ}$ research.

Lidar acquisition capabilities are increasing exponentially (Stennett, 2004; Glennie et al., 2013) and new ground-based (terrestrial laser scanning - TLS), mobile platforms (airborne laser scanning - ALS, or other mobile platforms like trucks or boats), and space-based platforms (spaceborne laser scanning - SLS) are leading to increased availability of lidar data sets with CZ-relevant information content. Different lidar platforms each have their own advantages and limitations, but operate based on a similar principle by emitting and measuring the round-trip time of travel of an energy pulse (laser light), and thus measuring and mapping distance to a target. Collection via TLS methods, for example, typically involves lidar scanners that are mounted on tripods or other fixed locations. Fixed targets surveyed with a high-resolution GPS are used to georeference the lidar data sets and to composite multiple TLS scans into a single point cloud. TLS scanners are becoming more affordable and available to individual researchers and groups. Lidar collections via mobile platforms are typically performed by mounting the lidar unit on an aircraft, helicopter, or vehicle that moves over the study area of interest. The aircraft must be equipped with a GPS unit and internal measurement unit (IMU) to track the orientation and location of the scanner. Similar to TLS collection, ALS methods require ground targets with known GPS locations for georeferencing. Lidar collection via SLS is much less common, but has been successfully deployed on orbiting spacecraft and will become more prevalent in 2017 with the planned launch of ICESat-2 (Ice, Cloud, and land Elevation Satellite) (Abdalati et al., 2010). In addition to the laser system, the spacecraft must have a GPS unit and altitude determination system in order to georeference the data. Each of these lidar platforms offer specifications that can be selected and adjusted for a given science application. Throughout this review we present studies using a suite of lidar methods and highlight the advantages of each method for differing scientific purposes.

The objective of this paper is to present a 5-year vision for applying lidar to advance transdisciplinary $\mathrm{CZ}$ research. To accomplish this, we first present the state of the science on applying lidar to disciplinary-specific research in geomorphology, hydrology, and ecology in Sect. 1.1, 1.2, and 1.3, respectively. This is followed in Sect. 2.1 by an exploration of transdisciplinary studies that have utilized complementary lidar-derived data sets to propel $\mathrm{CZ}$ science beyond what is possible within disciplinary endeavors. We summarize these exemplar transdisciplinary studies with the intent to guide future research. In Sect. 2.2 we describe how lidar-derived information is uniquely suited to advance three $\mathrm{CZ}$ research topics beyond the current state of the science: (1) quantifying change detection, (2) parameterization and verification of physical models, and (3) improved understanding of $\mathrm{CZ}$ 
processes across multiple scales. These topics are limited by a set of common impediments that we outline in Sect. 2.3. Finally, in Sect. 2.4, we present a vision to advance CZ science with lidar using examples of transdisciplinary research questions and provide a set of recommendations for the $\mathrm{CZ}$ community to increase usage and advocate for greater lidar resources over the next 5 years.

\subsection{Advances in geomorphology using lidar}

High-resolution topographic data sets derived from lidar have greatly contributed to quantifying geomorphic change, identifying geomorphic features, and understanding ecohydrologically mediated processes at varying scales and extents. These advances have allowed testing of geomorphic models, pattern and process recognition, and the identification of unanticipated landforms and patterns (e.g., waveforms) that were not possible using previous survey techniques. Generally, lidar information complements rather than replaces field observations, with lidar observations leading to new hypotheses and process cognition (Roering et al., 2013). Broadly, lidar technology has been useful in studying geomorphic response to extreme events such as fire and storms (e.g., Pelletier and Orem, 2014; Sankey et al., 2013; Perignon et al., 2013; Staley et al., 2014), human activities (e.g., James et al., 2009), and past climatic and tectonic forcings (e.g., Roering, 2008; Belmont et al., 2011; West et al., 2014). Meter- and sub-meter-scale time-varying processes, often derived from TLS, have been quantified in the response of point bar and bank morphodynamics (Lotsari et al., 2014) and in the formation of micro-topography due to feedbacks with biota (e.g., Roering et al., 2010; Pelletier et al., 2012; Harman et al., 2014). Examples of larger scale change detection applications, typically ALS-derived, include measuring changes in stream channel pathways resulting from Holocene climate change and anthropogenic activities (e.g., Day et al., 2013; Kessler et al., 2012; James et al., 2012; Belmont et al., 2011), rates of change in migrating sand dunes (Pelletier, 2013), the influence of lithology and climate on hillslope form (e.g., Marshall and Roering, 2014; Hurst et al., 2013; Perron et al., 2008; West et al., 2014), and channel head formation (e.g., Pelletier et al., 2013; Pelletier and Perron, 2012; Perron and Hamon, 2012). Automated tools to identify geomorphic features (e.g., floodplains, terraces, landslides) and transitional zones (e.g., hillslope-to-valley, floodplain-tochannel) have been used in conjunction with high-resolution elevation data sets from lidar, including Geonet 2.0 (Passalacqua et al., 2010), ALMTools (Booth et al., 2009), and TerrEX (Stout and Belmont, 2014).

\subsection{Advances in hydrology using lidar}

Research utilizing lidar has advanced fundamental process understanding in snow hydrology (Deems et al., 2013), surface water hydraulics (Lane et al., 2004; Nathanson et al.,
2012; Lyon et al., 2015), and land-surface-atmosphere interactions (Mitchell et al., 2011). Lidar-derived snow depths (derived by differencing snow-on and snow-off elevations) over large $\left(>1 \mathrm{~km}^{2}\right)$ spatial extents from both ALS and TLS (Deems et al., 2013) have yielded unprecedented contiguous maps of spatial snow distributions (e.g., Fassnacht and Deems, 2006; McCreight et al., 2014) and provided new insights into underlying processes determining spatial patterns in snow cover (von Trujillo et al., 2009; Kirchner et al., 2014), accumulation and ablation rates (Grunewald et al., 2010; Varhola and Coops, 2013), snow water resource planning (Hopkinson et al., 2012), and estimating the effects of forest cover and forest disturbance on snow processes (Harpold et al., 2014a). Change detection techniques have been effective for determining glacier mass balances (Hopkinson and Demuth, 2006), ice surface properties (Williams et al., 2013), and calving front movements (e.g., Arnold et al., 2006; Hopkinson and Demuth, 2006). Prior to lidar, many of these cryospheric processes had to be investigated using single point observations or through statistical rather than deterministic analyses; the additional information derived from lidar has yielded important insights that have advanced scientific understanding. High-resolution topographic information from lidar has proved important for stream channel delineation (Kinzel et al., 2013), rating curve estimation (Nathanson et al., 2012; Lyon et al., 2015), floodplain mapping and inundation (Marks and Bates, 2000; Kinzel et al., 2007), and topographic water accumulation indices (Sørensen and Seibert, 2007; Jensco et al., 2009). Lidar measurements of micro-topography shows potential for improving soil property and moisture information (e.g., Tenenbaum et al., 2006), surface and floodplain roughness (Mason et al., 2003, Forzieri et al., 2010; Brasington et al., 2012; Brubaker et al., 2013), hydraulic dynamics and sediment transport (Roering et al., 2009; McKean et al., 2014), surface ponding and storage volume calculations ( $\mathrm{Li}$ et al., 2011; French, 2003), and wetland delineation (e.g., Lane and D'Amico, 2010). Certain hydrological modeling fields are well poised to utilize high-resolution topography, such as movement of water in urban environments (Fewtrell et al., 2008), in-channel flow modeling (Mandlburger et al., 2009; Legleiter et al., 2011), and hyporheic exchange and ecohydraulics in small streams (e.g., Wheaton et al., 2010b). Finally, high-resolution, three-dimensional lidar measurements of canopy and vegetation structure (Vierling et al., 2008) have direct implications for modeling the surface energy balance (Musselman et al., 2013; Broxton et al., 2014) and evapotranspiration processes (Mitchell et al., 2011) at scales critical to increasing fidelity in physically based models.

\subsection{Advances in ecology using lidar}

Lidar-based remote sensing of vegetation communities has transformed the way ecologists measure vegetation across multiple spatial scales (e.g., Lefsky et al., 2002; Maltamo 
et al., 2014; Streutker and Glenn, 2006). Substantial work has been undertaken using lidar to map vegetation structure and biomass distributions (see reviews by Seidel et al., 2011 and Wulder et al., 2012). These include the estimation of leaf area index (LAI; Riaño et al., 2004; Richardson et al., 2009; Hopkinson et al., 2013), vegetation roughness (Streuker and Glenn, 2006; Antonarakis et al., 2010), alpine tree lines (Coops et al., 2013), and total carbon storage and sequestration rates in forest, grassland, savannahs, and/or shrubland communities (Asner et al., 2012a; Baccini et al., 2012; Mascaro et al., 2011; Simard et al., 2011; Antonarakis et al., 2014). ALS has been used to characterize wildlife habitat in tree and shrub canopies (Hyde et al., 2005; Bork and $\mathrm{Su}, 2007$; Vierling et al., 2008; Martinuzzi et al., 2009; Zellweger et al., 2014) and in aquatic systems (McKean et al., 2008; Wedding et al., 2008; McKean et al., 2009). ALS has been a critical tool in modeling catchment-scale water availability for vegetation at fine (Harmon et al., 2014) and broad spatial scales (Chorover et al., 2011). Radiation transmission and ray-tracing models utilizing lidar provide ecologists with better tools to quantify in-canopy and below-canopy light environments (Lee et al., 2009; Bittner et al., 2014; Musselman et al., 2013; von Bode et al., 2014; Moeser et al., 2014). Additionally, ecologists are beginning to quantify the impact of vegetation on micro-topography (Sankey et al., 2010; Pelletier et al., 2012; Harmon et al., 2014), as well as larger landform processes (Pelletier et al., 2013). Broad-scale lidar data allow for quantification of patches and mosaics amongst plant functional types across landscapes (Antonarakis et al., 2010; Dickinson et al., 2014) and global forest biomass estimates (Simard et al., 2011). Ecologists have fused data from hyperspectral imaging and lidar to enable species classification for close to a decade (e.g., Mundt et al., 2006). However, new opportunities exist to link species-level detail and plant functional response through emerging technologies, including co-deployment of hyperspectral and lidar sensors (Asner et al., 2012b), and hyperspectral (supercontinuum) laser technology (Kaasalainen et al., 2007; Hakala et al., 2012). By linking lidar with additional observations, researchers have begun to quantify species-level detail and plant health estimation (Cho et al., 2012; Féret and Asner, 2012; Olsoy et al., 2014) and model forest carbon fluxes (Antonarakis et al., 2014).

\section{Current toolkits and open questions using lidar in CZ science}

Research based on lidar-derived information accounts for substantial advances within the cornerstone $\mathrm{CZ}$ disciplines. However, many open questions in $\mathrm{CZ}$ science require linked, transdisciplinary investigations across multiple disciplines that create new intellectual spaces for scientific advancements. For example: how do CZ processes co-evolve over long timescales and interact over shorter timescales to de- velop thresholds and shifts in states and fluxes of water, energy, and carbon? What will be the response of the CZ structure to disturbance and land use change? These $\mathrm{CZ}$ science questions must elucidate feedbacks and interactions among the geosphere, ecosphere, and hydrosphere. This cannot be accomplished within the individual disciplines (multidisciplinary) or by sharing information across disciplines (interdisciplinary), but instead require synergistic transdisciplinary science that spans multiple spatial and temporal scales.

A key advantage of lidar for understanding $\mathrm{CZ}$ feedbacks is the coupling of previously unprecedented coverage over both broad temporal and spatial scales (Fig. 1). The utility of lidar for geosphere, ecosphere, and hydrosphere investigations is dependent on the platform (e.g., TLS, ALS, or SLS) with cross-platform observations capable of resolutions from $10^{-3} \mathrm{~m}$ to continental scales (Fig. 1). In terms of temporal extent, TLS, ALS and SLS are capable of employing weekly to sub-hourly repeat scan rates (Fig. 1). Technologies allowing for faster scan rates will typically limit the spatial extent (Fig. 1). Advances in technology described in Sect. 2.3 will increase the spatial and temporal resolutions for all lidar platforms in the next 5 years (Fig. 1). The intersecting process scales shown in Fig. 1 demonstrate the viability of extracting transdisciplinary information from lidar given thoughtful experimental design and data collection.

\subsection{Lidar as a transdisciplinary $\mathrm{CZ}$ tool}

To investigate the state of the science of lidar in $\mathrm{CZ}$ research we conducted a literature review of 147 peer-review papers that employed lidar data sets to improve process-based understanding. Our review found that most lidar studies to date have had a single disciplinary objective and that the $\mathrm{CZ}$ community is does not typically use the overlapping information in space and time generated by lidar (Fig. 1). This is not surprising given the rampant progress made in filling important knowledge gaps in the individual cornerstone $\mathrm{CZ}$ disciplines using lidar data sets (Sect. 1.1 to 1.3). We organized the literature reviewed for this paper into a scoring system of geomorphic, hydrologic, and ecologic process knowledge advanced through individual lidar-based studies. For each paper we assigned 10 points among the three disciplines to capture potential transdisciplinary lidar use. For example, a study leading purely to hydrologic process advances would rank as 10 in the hydrology category and 0 in the ecology and geomorphology categories. A study balancing the process-based inferences among the three disciplines, with a more prominent ecological focus, would have been assigned scores of 3,3 , and 4 for geomorphology, hydrology, and ecology, respectively. Of course, this is a subjective scaling based on author opinions. To limit potential impacts of subjectivity, three different authors of the current paper assigned independent scores to each study and we used the average score to place each paper in the relative ranking triangle (Fig. 2). 

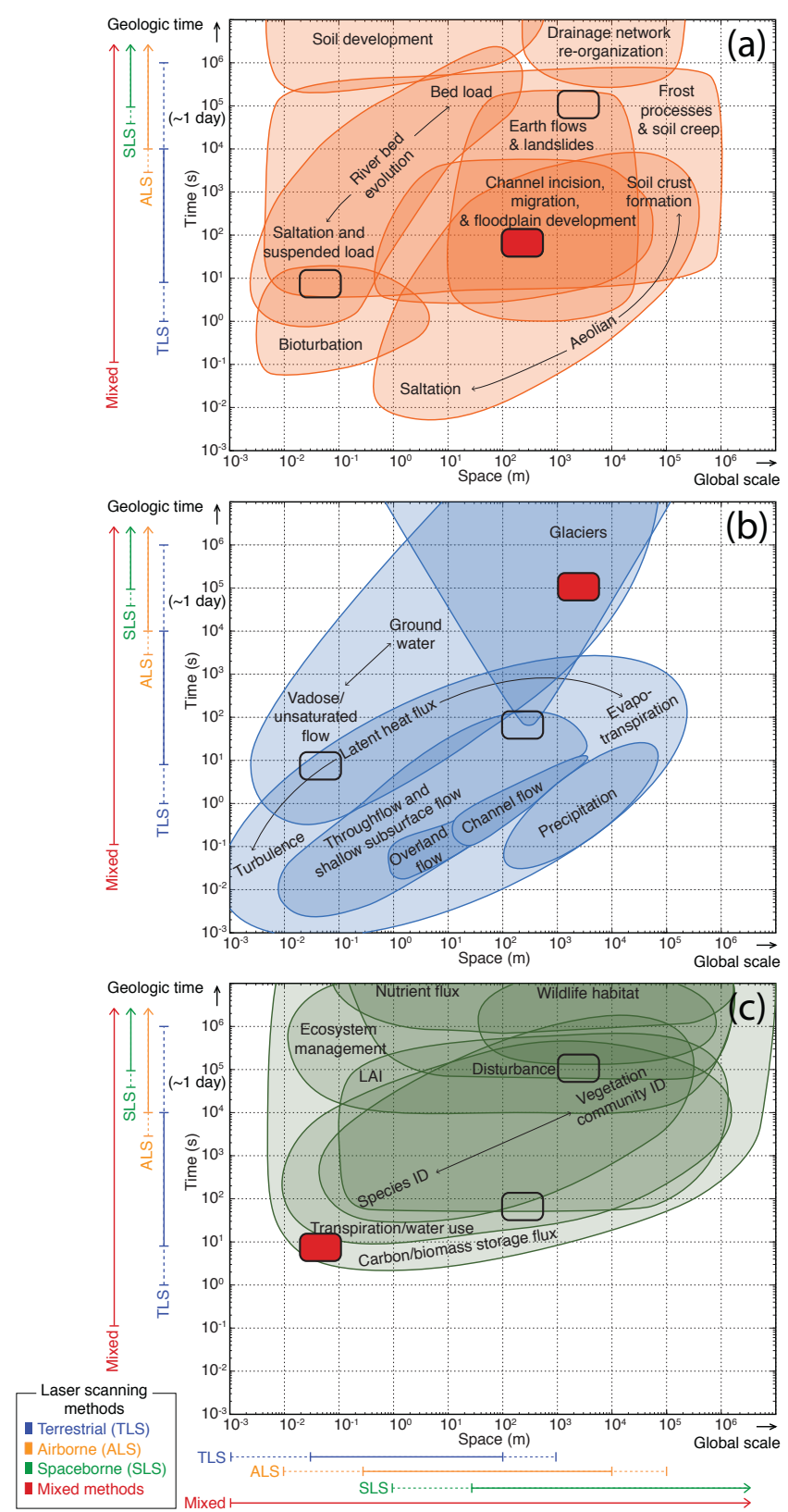

Figure 1. Important $\mathrm{CZ}$ processes graphed as a function of time versus space for geomorphology (a), hydrology (b), and ecology (c). The spatial and temporal scales that lidar is currently addressing are shown as colored bars, with dotted bars indicating increasing resolutions and larger extents available in the next 5 years. Overlapping spatiotemporal scales that encompass the example questions in the Fig. 3 are also noted with red boxes.

The motivation for developing the conceptualization in Fig. 2 is to facilitate identification of studies employing transdisciplinary synergies (e.g., lie within the internal triangle) that rely on the multi-faceted nature of lidar data sets. The review showed $38 \%$ of 147 studies were focused (score of 6 or higher) in geomorphology, $18 \%$ in hydrology, $32 \%$ in

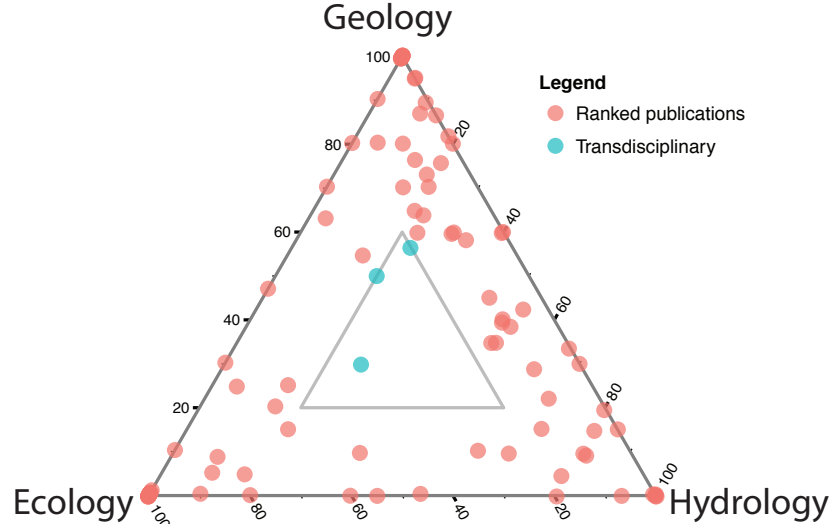

Figure 2. Depiction of the disciplinary focus of 147 journal articles using lidar. Articles were qualitatively ranked based on their applicability to geomorphological, hydrological, and/or ecological process understanding. Articles in the center are examples of transdisciplinary lidar applications, with those shown in blue used as exemplars in the text.

ecology, and the remainder had a more interdisciplinary focus. The few studies in the center of the triangle could be considered as potential exemplars of $\mathrm{CZ}$ science using lidar as they balance well among each cornerstone discipline. Several studies were transdisciplinary in nature, but focused on lidar-derived topography and did not maximize information content on hydrological and ecological processes from lidar (Pelletier et al., 2012, Persson et al., 2012, Brubaker et al., 2013, Pelletier, 2013, Coops et al., 2013, Rengers and Tucker, 2014, and Pelletier and Orem, 2014). We instead draw focus to transdisciplinary studies that demonstrate the potential for complementary information to be extracted from lidar and integrated into field campaigns to allow multi-scale observations of interacting geomorphologic, hydrologic, and ecologic processes.

We highlight three studies that can serve as possible road maps to guide future transdisciplinary investigations using lidar data sets (Fig. 2): Harman et al. (2014), Pelletier et al. (2013), and Perignon et al. (2013). These studies used complementary information from lidar to develop fundamental transdisciplinary advances in the theories and understanding of $\mathrm{CZ}$ processes and structure. For example, Harman et al. (2014) applied TLS to investigate co-evolution of lidarderived micro-topography and vegetation (biovolume) at two $100 \mathrm{~m}$ long semi-arid hillslopes. Integrating lidar and limited field measurements, Harman et al. (2014) found that both alluvial and colluvial processes were important in shaping vegetation and soil dynamics on hillslopes. The insights found by Harman et al. (2014) relied on the high resolution and precision of lidar information and would not have been possible using coarser traditional survey techniques for topography and vegetation structure. Pelletier et al. (2013) investigated landscape-scale $\left(>10 \mathrm{~km}^{2}\right)$ variability in aboveground 
biomass, hydrologic routing, and topography derived from lidar at two mountain ranges in southern Arizona and applied a landscape evolution model to demonstrate the need to include ecological processes (e.g., vegetation density) to correctly model topography. Lidar-derived vegetation structure provided new information not attainable from other methods that allowed for Pelletier et al. (2013) to test a novel model of CZ development based on eco-pedo-geomorphic feedbacks. Perignon et al. (2013) investigated topographic change following a major flood along a $12 \mathrm{~km}$ stretch of the Rio Puerco in New Mexico. They found that sedimentation patterns reflected complex interactions of vegetation, hydraulics, and sediment at the scale of individual plants. This example demonstrates the value of lidar for testing ecohydrological resilience to extreme events and to develop new understanding of the fine-scale ecological feedbacks (i.e., individual plants) on reach-scale geomorphic response.

These exemplar studies demonstrate the utility of lidar for transdisciplinary process investigations at scales ranging from hillslopes (e.g., Harman et al., 2014), to stream reaches (e.g., Perignon et al., 2013), to mountain ranges (e.g., Pelletier et al., 2013). We believe that these exemplar transdisciplinary studies should serve as motivation for increased use of lidar and integrated, multi-scale field observations for advancing $\mathrm{CZ}$ science. To this end, in Sect. 2.4 we provide additional examples to illustrate the overlapping processes observable with lidar that are motivated by $\mathrm{CZ}$ science questions.

\subsection{Applying lidar in CZ science}

Through our literature review and subsequent conceptualizations (e.g., Fig. 1) we have identified three clear areas where lidar observations have the potential to advance the state of CZ science in the next 5 years: (1) quantifying change detection, (2) parameterization and verification of physical models, and (3) improving understanding of $\mathrm{CZ}$ processes across multiple scales. These tools are not mutually exclusive and each area has different levels of previous research and development. For example, change detection utilizing lidar has received notable use in the $\mathrm{CZ}$ science community, particularly by geomorphologists analyzing topographic change over time. The use of lidar to quantify scaling relationships and thresholds remains relatively unexplored, despite robust scaling theories and analysis tools from other fields that are portable to lidar data sets. Similarly, integration of lidar data sets for either parameterization or verification has had limited development within CZ-relevant models.

\subsubsection{Change detection}

Lidar-based change-detection analyses (CDA), i.e., mapping landscape adjustments through time in multi-temporal ALS and TLS data sets, have provided comprehensive measurements of snow depth (e.g., Harpold et al., 2014b; Tinkham et al., 2014) and ablation (Egli et al., 2011), co-seismic displacements after earthquakes (e.g., Oskin et al., 2012; Nissen et al., 2014), changes in aeolian dune form and migration rates (e.g., Pelletier, 2013), fluvial erosion (e.g., Anderson and Pitlick, 2014; Pelletier and Orem, 2014), earthflow displacements (e.g., DeLong et al., 2011), knickpoint migration in gully/channel systems (e.g., Rengers and Tucker, 2014), cliff retreat along coasts (Young et al., 2010), permafrost degradation (Levy et al., 2013; Barnhart and Crosby, 2013), forest growth (Yu et al., 2004; Næsset and Gobakken, 2005), and changes in biomass (e.g., Meyer et al., 2013; Olsoy et al., 2014). Traditionally, lidar point clouds have been rasterized prior to differencing using open-source processing toolkits (e.g., GCD (Geomorphic Change Detection); e.g., Wheaton et al., 2010a). However, new methods such as iterative closest point (Nissen et al., 2012), particle image velocimetry (Aryal et al., 2012), and Multiscale Model to Model Cloud Comparison (Lague et al., 2013) enable direct differencing of point clouds. Continued methodological advances, coupled with increasingly available repeat data sets will progress the capabilities and quality of CDA. Structure from Motion (SfM) estimates three-dimensional structures from two-dimensional images providing an easily portable and low-cost method for making high-frequency change detection measurements (Westoby et al., 2012; Fonstad et al., 2013; James and Robson, 2012). There is also potential to apply time-series multi/hyperspectral lidar data sets to quantify changes in forest health over time. Similarly, integration of bathymetric lidar with ALS opens the potential to monitor dynamic changes in streambed morphology, river flow, and sediment transport (Flener et al., 2013). Although researchers often implement CDA using historic data sets (Rhoades et al., 2009), challenges arise from sparse metadata and reduced accuracy, thereby limiting data set utility (e.g., Glennie et al., 2014). Future CDA may be improved by further establishing best practices for data set sharing and archiving through repositories such as OpenTopography and UNAVCO.

\subsubsection{Scaling $\mathrm{CZ}$ processes}

While researchers have harnessed existing scaling theories and tools utilizing lidar data sets, there is room for expansion using the range of scales afforded by lidar technologies (Fig. 1). Two complementary techniques, characterizing fractal patterns (e.g., Deems et al., 2006; Glenn et al., 2006; Perron et al., 2008) and process changes expressed as fractal breaks (e.g., Drake and Weishampel, 2000), benefit from the extensive breadth of spatial scales offered by lidar data. Self-similar patterns across scales indicate consistent processes and thus provide a framework for sampling, modeling, and re-scaling processes. Variograms and semivariograms are commonly employed to plot lidar-derived attributes of interest such as snow distribution (e.g., Deems et al., 2008; Harpold et al., 2014a) or forest spatial patterns (e.g., Boutet et al., 2003) against scale. Fractal and fractal 
deviations, as well as the length-scales of landscape structure (Perron et. al., 2008), convey important CZ information, e.g., the effect of tree-root spacing through time on soil production (Roering et al., 2010), patterns in tree gap formation (Plotnick et al., 1996; Frazer et al., 2005), and underlying abiotic and biotic controls on forest fractal dimensions (Drake and Weishampel, 2000). Within the CZ framework, lidar allows for consideration of topographic variation and biomass distribution (Chorover et al., 2011), and spatial thresholds for interactions among vegetation, hydrology, lithology, and surface processes ranging from the grain to landscape scale (e.g., Musselman et al., 2013; Pelletier et al., 2013; Harman et al., 2014). Zhao et al. (2009) developed a scale-invariant model of forest biomass, which illustrated the utility of scaleindependent methods. However, we caution that one scientist's signal may be another's noise (Tarolli, 2014). Signal recognition may involve smoothing at one scale to quantify a relevant landscape metric, such as hillslope curvature (and derived erosion rates; Hurst et al., 2013), which in turn limits valuable information at another scale, such as hydrologically driven surface roughness or the spacing of tree-driven bedrock disruption (Roering et al., 2010; Hurst et al., 2012). Overall, lidar data sets retain the promise of up- or downscaling feedbacks among multiple processes that are just beginning to be fully utilized.

\subsubsection{Model parameterization and verification}

The wealth of recently collected lidar data has the potential to inform the choice of physically based model parameters and verify model output. Improved terrain representation has helped characterize hysteretic relationships between water storage and contributing area in large wetland complexes within parameterized runoff models (Shook et al., 2013), improved mapping in and along river channels to parameterize network-level structure and flood inundation models (French, 2003; Kinzel et al., 2007; Snyder, 2009; Bates, 2012), and expanded investigation of geomorphological change in floodplains (Thoma et al., 2005; Jones et al., 2007). Lidar provides vertical information that permits the direct retrieval of forest attributes such as tree height and canopy structure (Hyyppä et al., 2012; Vosselman and Maas, 2010) that can be used to model canopy volume (Palminteri et al., 2012), biomass (Zhao et al., 2009), and the transmittance of solar radiation (Essery et al., 2008; Musselman et al., 2013; von Bode et al., 2014). Lidar has also proven to be instrumental in the verification of model states. For example, lidar data sets have been used to verify physically based models, including landscape evolution models (Pelletier et al., 2014; Pelletier and Perron, 2012; Rengers and Tucker, 2014), aeolian models (Pelletier et al., 2012; Pelletier, 2013), physiological models (Coops et al., 2013), snowpack energy balance models (Essery et al., 2008, Broxton et al., 2014), and an ecosystem dynamics model (Antonarakis et al., 2014). Simpler, empirical models have also been developed using lidar-derived estimates of soil erosion (Pelletier and Orem, 2014) and snow accumulation and ablation (Varhola et al., 2014). Better recognition of the potential benefits of lidar for model calibration and verification within $\mathrm{CZ}$ modeling communities could lead to increased utilization and targeted acquisitions in the future.

\subsection{Adoption and utilization of lidar data sets}

New and improved lidar data sets are more likely to result in transformative $\mathrm{CZ}$ science if a number of key opportunities (and impediments) are recognized. The research topics discussed in Sect. 2.2 require attention to four key areas in order to maximize the applicability of lidar in CZ science: (1) emerging data acquisition technologies, 2) availability of processing and analysis techniques, (3) linkages to in situ observations, and (4) linkages to other remote-sensing observations. The first two areas recognize the importance of technological advances and information sharing to enhance lidar data quality and coverage. The second two areas demonstrate the potential to extend scientific inferences made from lidar with linkages to multiple, complementary observations.

\subsubsection{Data acquisition technology}

Future advances in data acquisition technologies will provide greater information and spatiotemporal coverage from lidar (and similar high-resolution remote sensing technologies) data sets. Several new lidar technologies are rapidly improving data quality (accuracy, precision, resolution, etc.) and information content. Full waveform lidar data promises to provide a better definition of ground surface and vegetation canopy (Wagner et al., 2008, Mallet and Bretar, 2009). Utilizing blue-green light spectrum, lidar systems are capable of bathymetric profiling (McKean et al., 2009; Fernandez-Diaz et al., 2014) and potentially determining turbidity and inherent optical properties of the water column. Lidar systems have demonstrated the benefits of combining point clouds with alternative data sources by, for example, including intensity and/or RGB cameras (Bork and Su, 2007) that collect data synchronously with the lidar and provide metadata for each point in the cloud. Less expensive and more adaptable lidar systems (Brooks et al., 2013) and alternative 3-D remote sensing techniques, such as SfM or low-cost 3-D cameras (Mankoff and Russo, 2013; Javernick et al., 2014; Lam et al., 2015), promise high-resolution monitoring at finer temporal resolutions and lower costs. Increasingly, lidar observations are combined with passive electro-optical multispectral and hyperspectral images (Kurz et al., 2011). Lidar technology already includes active multispectral laser systems, and hyperspectral laser observations of object reflectance are likely only 3 to 5 years away (Hakala et al., 2012; Hartzell et al., 2014). These systems promise to lessen the need for multiple sensors, thus reducing uncertainties due to data registration, lowering costs, and reducing processing time. The combination of these technologies holds promise as a means to cost- 
effectively monitor aspects of the $\mathrm{CZ}$ at timescales of days or less and information content that includes not only 3-D structure but also spectral information that is potentially capable of determining vegetation composition and health, soil and exposed bedrock composition, and soil water content.

In addition to emerging lidar acquisition systems, new and existing collection platforms are substantially broadening data coverage. Collection of lidar from fixed-wing aircraft is expanding to national scales through programs such as the U.S. Geological Survey's 3-D Elevation Program (3DEP), Switzerland's national lidar data set collected by the Federal Office of Topography, Sweden's Lantmäteriet (http://www.lantmateriet.se), Netherlands' Public Map Service (http://www.pdok.nl/en/node), Denmark's Geodata Agency (http://gst.dk), Finland's National Land Survey (http://www.maanmittauslaitos.fi/en/maps-5), United Kingdom's Environment Agency (http://www.geomatics-group. co.uk/GeoCMS), and Australia's AusCover (http://www. auscover.org.au/). Additionally, acquisition of aircraft and lidar systems by institutional research programs have led to greater capabilities for ecological research by the National Ecological Observatory Network (Kampe et al., 2010) and snow water resources via NASA's Airborne Snow Observatory (http://aso.jpl.nasa.gov). Institutional systems and operational expertise are also available for short-term research projects across a range of Earth science applications (Glennie et al., 2013) via the National Center for Airborne Laser Mapping (NCALM) and UNAVCO. Of particular interest to the $\mathrm{CZ}$ community is the development of unmanned aerial systems (UASs) that are capable of mounting small lidar systems for rapid deployment (Lin et al., 2011; Wallace et al., 2012). Long-range UASs offer the potential for repeat lidar acquisitions at a fraction of the cost of current ALS platforms. Best practices for collecting, processing, and analyzing lidar over increasing extents (i.e., continental scales) are generally lacking, which can limit the effectiveness of data sets collected over vastly different physiographic conditions.

\subsubsection{Data access, processing, and analysis}

The crux of successfully leveraging a flood of new lidar (and other high-resolution topographic information) data for $\mathrm{CZ}$ science (e.g., Stennett, 2004) will be the ability to extract meaningful information from these rich and voluminous data sets. These new lidar data sets require that data processing and analysis tools be optimized to handle increasingly large data sets with greater information content. Processing limitations are likely to reduce the usability and extent of very high information data sets, e.g., waveform or multispectral data sets pose processing challenges at the continental scale but may be more manageable at the watershed scale. Further, new software and workflows need to be developed that enable scientists to incorporate lidar data into detailed models of the $\mathrm{CZ}$ without expertise in remote sensing. The $\mathrm{CZ}$ science community must engage in a concerted effort to develop (and/or adopt from other domains) new open-source tools that leverage high performance computing resources available through programs such as the National Science Foundation (NSF) Extreme Science and Engineering Discovery Environment (XSEDE) (https://www.xsede.org/home). By increasing the scalability of $\mathrm{CZ}$ lidar-oriented processing and analysis tools, computationally intensive analysis and modeling at the highest resolution of the lidar data sets will be possible. In addition to increasing software scalability, new processing tools are necessary to take advantage of new data types, such as full waveform lidar (Wagner et al., 2008, Mallet and Bretar, 2009) and hyperspectral laser technology (Hakala et al., 2012). Cloud computing and the "big data paradigm" that is increasingly common in both industry and academia (Mattman, 2013) present opportunities for the CZ lidar community. One such opportunity for big data sharing is EarthCube (http://www.earthcube.org), a relatively new program that has potential to integrate lidar information (among other geospatial information) into data sharing efforts in the geosciences. Due to efforts such as NSF's OpenTopography (Crosby et al., 2011), there is a large volume of CZ-oriented lidar online and freely available to the community. For example, OpenTopography already offers on-demand processing services (Krishnan et al., 2011) that permit users to generate standard and commonly used derivatives from the hosted lidar point cloud. By coupling data processing with data access, users are not required to download large volumes of data locally or have the dedicated computing and software resources to process these data. Although many CZ-oriented lidar data sets are already available to the community through resources such as OpenTopography in the USA, there are numerous other lidar data sets globally that are not accessible because they are not available online or access is restricted. Many of these "legacy" data sets are likely to be important temporal baselines for comparison against future data sets (Glennie et al., 2014; Harpold et al., 2014a).

\subsubsection{Linkages to in situ observations}

Many CZ studies have incorporated in situ observations to extend or confirm inferences made with lidar-derived data sets. In situ measurements are time consuming to collect, often expensive to analyze, and limited in terms of spatial coverage. As a result, researchers must be judicious with in situ data collection and maximize integration with lidar data sets. Physical and chemical properties of soil and rock, and vegetation structure are among the in situ observations commonly integrated with lidar data sets. For example, lidarbased studies have integrated distributed measurements of soil hydraulic properties (Harman et al., 2014) and soil thickness (Roering et al., 2010; Pelletier et al., 2014; West et al., 2014), as well as radioactive isotopes in soils (West et al., 2014). Lidar data sets have also been used to extend in situ observations of snow depth (Harpold et al., 2014a; Varhola and Coops, 2013) and carbon fluxes (Hudak et al., 2012) in 
both space and time. In situ observations of vegetation structural characteristics are commonly made to develop relationships with lidar observations and extend these relationships for forest inventory (e.g., Wulder et al., 2002). In addition to scientific inferences, lidar can be used to improve sampling design to reduce field time and analytical expenses. For example, lidar has improved insight into sampling snow measurements necessary for water management (McCreight et al., 2014). A number of challenges remain to link lidarderived information to in situ measurements, including poor GPS information for historical data sets, constraining the observational footprint of different measurements, and comparing lidar-derived metrics to typical field measurements. Despite these challenges, opportunities exist to better integrate historical measurements into lidar-based studies and develop new in situ observations that use lidar data sets to up-scale $\mathrm{CZ}$ processes.

\subsubsection{Linkages to satellite remote sensing}

Satellite observations of surface-altimetry, reflectance, permittivity, and atmospheric profiles provide observations of $\mathrm{CZ}$ processes at multiple spatiotemporal scales, frequently with global coverage. The high spatial resolution offered by lidar technology complements the regular temporal frequency of optical and radar satellite observations, which could be used to co-calibrate and co-validate these types of data sets. Satellites also provide another platform for lidar acquisition. There are numerous examples where lidar data sets have been used to calibrate and verify coarser estimates of vegetation, cryosphere (glaciers, permafrost, snowpacks, etc.), and geomorphic processes and states made via optical and radar satellites. For example, Mora et al. (2013) used detailed lidar measurements of vegetation structure to quantify the spatial and temporal scalability of aboveground biomass of continental forests measured with a very high spatial resolution (VHSR) satellite. In data-limited regions of Uganda, lidar fused with Landsat data sets have improved modeled biomass predictions and understanding of phenologic processes (Avitable et al., 2012). Varhola and Coops (2013) and Ahmed et al. (2014) introduce methods for detecting changes in vegetation structure and function from disturbance by fusing Landsat and lidar measurements, and Bright et al. (2014) used similar fused data sets to investigate changes following forest mortality. Applications combining lidar and satellite measurements to change detection have also been applied to evaluate the effects of vegetation on snowpack dynamics (Varhola et al., 2014) and for comparison with model and satellite-derived estimates of snow-covered area (Kirchner et al., 2014; Hedrick et al., 2015). A multi-faceted approach for the prediction and monitoring of landslides by Guzzeti et al. (2012) used measurements from optical satellites and lidar. The Ice, Cloud, and land Elevation Satellite (ICESat) was a NASA mission from 2003 to 2009 that mapped changes in glacier mass balance using SLS (Kohler et. al. 2013). Scientists have used the ICESat Geoscience Laser Altimeter System (GLAS) to identify areas of forest regeneration along the Mississippi (Li et al., 2011) and it has been applied in development of a global forest height map (Simard et al., 2011). A second mission (ICESat-2) is slated to launch in 2017 and while focused on ice sheet and sea ice change, it will provide complementary products to characterize terrestrial ecology. Furthermore, other current and future satellite missions will provide $\mathrm{CZ}$ observations that integrate with lidar, including soil moisture, groundwater storage, soil freeze/thaw, carbon flux, and primary productivity (Schimel et al., 2013). Of particular interest might be the Surface Water and Ocean Topography (SWOT) mission that provides coarse water and land topography using radar that has potential to complement finer-scale measurements acquired with lidar. To fully realize the potential information available from fused lidar and satellite data sets, critical attention must be paid to (1) efficient processing of large data sets that span collection platforms and spatiotemporal variability, and (2) maintaining expert knowledge in data interpretation (Mattmann, 2013).

\subsection{A proposed 5-year vision}

The fields of CZ science and lidar-based technology are both advancing rapidly. Here, we present a vision that keeps $\mathrm{CZ}$ researchers abreast of advances in lidar technologies and positions CZ science at the forefront of the lidar revolution, particularly with regards to new hardware, processing capabilities, and linkages with complementary observations. These ideas are guided by the recognition that lidar is capable of simultaneously observing process signatures from multiple $\mathrm{CZ}$ disciplines (Fig. 1). To elucidate this point, we discuss three examples of transdisciplinary CZ research questions and suggest how they could benefit from current and future lidar technologies. We also provide specific recommendations for $\mathrm{CZ}$ researchers working with (or considering working with) with lidar data sets. Our intent is to catalyze CZ interest in the transdisciplinary possibilities of lidar data sets, while increasing the influence of $\mathrm{CZ}$ scientists within the broader group of lidar end users.

Technological advances can be conceptualized as increasing data coverage, quality, and information, including new acquisition platforms or higher acquisition rates (Fig. 3). Other advances, such as full-waveform information or hyperspectral lasers, will increase the data quality and information content extractable from lidar data sets. Three examples of linked transdisciplinary research questions (Fig. 3) demonstrate the value of technological advances in lidar for CZ science: (1) how does co-variation between vegetation and hydrological flow paths control the likelihood and distribution of earth flows and landslides? (2) How is the rapidly changing cryosphere influencing hydrological connectivity, drainage network organization, nutrient and sediment fluxes, land-surface energy inputs, and vegetation struc- 


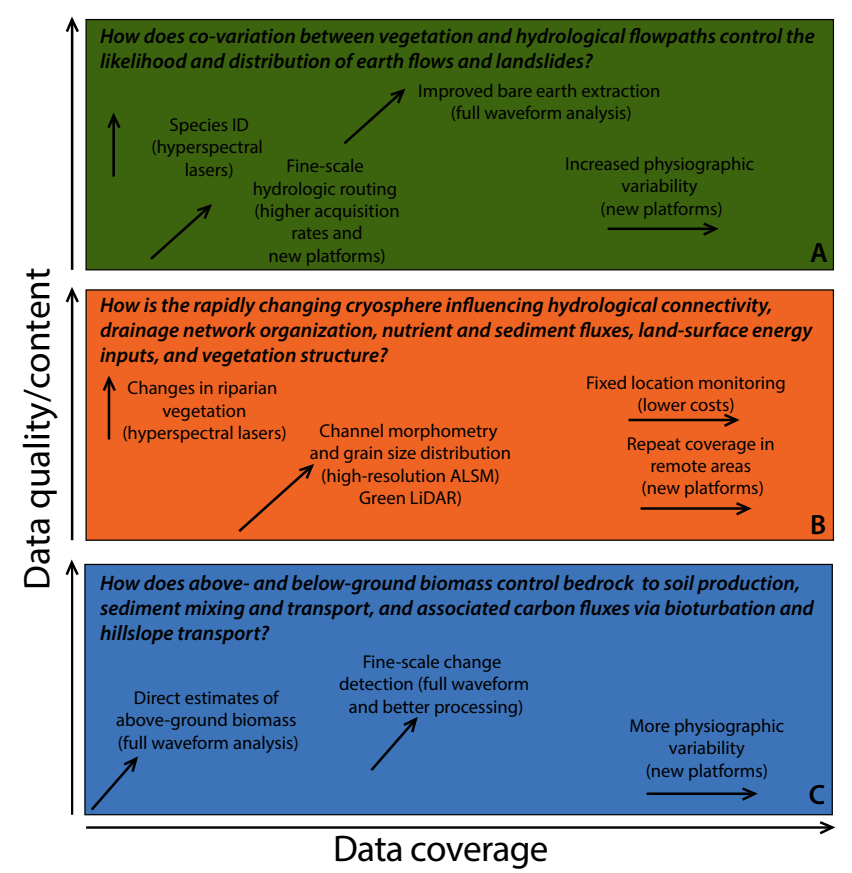

Figure 3. Example $\mathrm{CZ}$ research questions conceptualizing the transdisciplinary potential of lidar data sets when coupled with future technological advances. The questions encompass processes from geomorphology (a), hydrology (b), and ecology (c) that overlap spatial and temporal scales. These scales are noted in Fig. 1. The text in the panel notes specific improvements offered and the technology needed in parentheses. The arrows qualitatively represent whether the technological advance expands data coverage and/or data quality/content.

ture? (3) How does above- and belowground biomass control bedrock to soil production rates, sediment mixing and transport, and associated carbon fluxes via bioturbation and hillslope transport? These example questions demonstrate the need for research that transcends information sharing across disciplines to develop synergistic new theories and advances in CZ science.

These research questions span a wide-range of spatial and temporal scales, from smaller and faster $\left(\times 10^{-2} \mathrm{~m}\right.$ and $\left.\times 10^{1} \mathrm{~s}\right)$ in question 3 to larger and more long-term $\left(\times 10^{5} \mathrm{~m}\right.$ and $\times 10^{6} \mathrm{~s}$ ) in question 2 (see Fig. 1). Our ability to answer these questions benefits from several facets of improved lidar technologies, including higher acquisition rates and larger ranges, more rapid and robust deployment options, and improved processing resources for extracting information. Future lidar technologies could address question 1 by identifying specific vegetation species via hyperspectral laser technologies, increasing accuracy of bare-earth estimation to improve hydrologic routing using full-waveform analysis, and increasing coverage of landslide-prone areas from different physiographic regions (Fig. 3). New technology will address question 2 by providing estimates of riparian vegetation productivity, measuring channel bathymetry using blue-green li- dar, and with new platforms that increase sampling frequency via UASs or other low-cost systems. Lastly, new technology will address question 3 by providing improved estimates of aboveground biomass and bare-earth extraction using full waveform analysis, and improved fine-scale change detection with greater processing resources. These example questions and their conceptualization (Fig. 3) demonstrate what well-integrated lidar data sets can provide to stimulate and improve future $\mathrm{CZ}$ research.

We propose five recommendations as an attempt to unite the $\mathrm{CZ}$ community around improved utilization and advocacy of lidar technology in important transdisciplinary scientific contexts that integrate the opportunities and impediments discussed previously:

\section{Open lines of communication}

Develop communication within and among groups, including individual $\mathrm{CZ}$ disciplines, remote-sensing scientists, computer scientists, private industry, and funding agencies. Workshops have the potential to increase communication between "data users" and "data creators". CZ scientists must find ways to communicate their data acquisition specifications to the scientists and engineers who create lidar hardware and processing software through venues such as meetings with private industry, the development of advisory committees, and commentary pieces in trade journals that present a vision for the future needs of $\mathrm{CZ}$ scientists. Open communication among diverse $\mathrm{CZ}$ scientists is fundamental to developing collaborations capable of transdisciplinary advances. Working groups within $\mathrm{CZ}$ communities, like the critical zone exploration network (http://www.czen.org), and townhall meetings at international Earth science conferences have initiated sustainable communication venues. Future efforts focused on early-career $\mathrm{CZ}$ scientists that demonstrate the benefits of transdisciplinary efforts, such as focused conferences and pilot research projects, should be pursued.

\section{Increase information extraction}

Advocate for lidar repositories that are interoperable and broaden data access, as well as open-source and communitycentric processing resources. Ultimately, enhanced and streamlined data processing and analysis tools will enable $\mathrm{CZ}$ researchers to concentrate on understanding fundamental science problems instead of struggling with data access, processing, and analysis. Specifically, recent efforts focused on cloud storage and computing resources, and open source software tools could greatly aid this effort. Efforts to improve the efficiency of processing will become more important as the acquisition of lidar expands to continental scales. Information extraction at larger extents will require judicious tradeoffs between acquisition parameters and costs that consider variability in local physiographic conditions (i.e., higher sampling densities in areas with dense vegeta- 
tion cover and high topographic complexity). Programs to support open-source software and their long-term sustainability are required to support $\mathrm{CZ}$ science. Increasing open access to lidar data sets facilitates greater information extraction and the potential for meta-analysis studies. The value of open-access data sets will increase as improved processing tools become available. CZ scientists should also consider working with private lidar acquisition companies and their customers (i.e., forestry, mining, and urban planning organizations) to release what has previously been proprietary data to the public.

\section{Increase accessibility of lidar systems}

Advocate for new acquisition technologies that lower the cost of lidar collection and increase its availability, such as unmanned platforms and less expensive and longer-range lidar systems. Institutional acquisitions of lidar systems also significantly increase accessibility. Community-supported lidar systems available to researchers, through agencies such as UNAVCO and NCALM, should also be encouraged. A powerful advancement would be a "clearinghouse" where agencies and institutions could exchange information on lidar systems, seek expert advice on lidar acquisition, and potentially trade or rent hardware to better meet the needs of individual projects.

\section{Focus on key technologies}

Support the development of new lidar technologies that are useful for linking disciplinary observations. For example, our review has stressed the potential benefits for linking $\mathrm{CZ}$ functions to processes offered by hyperspectral laser technologies (Fig. 3). Other key technologies include new acquisition platforms (UASs) and improved open-source processing capabilities and open-source industry-standard data formats. The community should continue with a dialogue about critical technologies within $\mathrm{CZ}$ science venues in parallel with interactions with technology developers (as mentioned previously). The more united the $\mathrm{CZ}$ community is about the benefits of a particular technology (i.e., hyperspectral lidar) the more it can advocate within public and private sectors for its advancement.

\section{Link complementary observations}

Consider other remote-sensing observations that may be complementary to lidar (e.g., thermal, infrared, optical, and microwave). While fusing remote-sensing data is becoming more common, the value of lidar information to coarser remote-sensing products is vast and underutilized. Be mindful of the potential synergistic benefits of collecting lidar data over areas with in situ observations and vice versa, consider how to improve collection of in situ observations based on lidar information. In particular, in situ information collected during lidar data collection can be extremely valuable and difficult to substitute for at a later date. Maintain awareness of competing, less expensive technologies, such as SfM, that may be more appropriate in some conditions and geographical locations. The multi-scale nature of transdisciplinary research (Figs. 1 and 3) demands that lidar be integrated into a broader observational framework that does not neglect the value of in situ and coarser remote-sensing observations.

Acknowledgements. The workshop forming the impetus for this paper was funded by the National Science Foundation (EAR 1406031). Additional funding for the workshop and planning was provided to S. W. Lyon by the Swedish Foundation for International Cooperation in Research and Higher Education (STINT grant no. 2013-5261). A. A. Harpold was supported by an NSF fellowship (EAR 1144894). The use of specific commercial or open-source packages and tools in this paper does not imply a specific endorsement.

Edited by: Y. Fan

\section{References}

Abdalati, W., Zwally, H. J., Bindschadler, R., Csatho, B., Farrell, S. L., Fricker, H. A., Harding, D., Kwok, R., Lefsky, M., Markus, T., Marshak, A., Neumann, T., Palm, S., Schutz, B., Smith, B., Spinhirne, J., and Webb, C.: The ICESat-2 laser altimetry mission, Proc. IEEE, 98, 735-751, doi:10.1109/JPROC.2009.2034765, 2010.

Ahmed, O. S., Franklin, S. E. and Wulder, M. A.: Interpretation of forest disturbance using a time series of Landsat imagery and canopy structure from airborne lidar, Can. J. Remote Sens., 39, 521-542, doi:10.5589/m14-004, 2014.

Anderson, S. and Pitlick, J.: Using repeat lidar to estimate sediment transport in a steep stream, J. Geophys. Res.-Earth, 119, 621643, doi:10.1002/2013JF002933, 2014.

Antonarakis, A. S., Richards, K. S., Brasington, J., and Muller, E.: Determining leaf area index and leafy tree roughness using terrestrial laser scanning, Water Resour. Res., 46, W06510, doi:10.1029/2009WR008318, 2010.

Antonarakis, A. S., Munger, J. W., and Moorcroft, P. R.: Imaging spectroscopy- and lidar-derived estimates of canopy composition and structure to improve predictions of forest carbon fluxes and ecosystem dynamics, Geophys. Res. Lett., 41, 2013GL058373, doi:10.1002/2013GL058373, 2014.

Arnold, N. S., Rees, W. G., Devereux, B. J., and Amable, G. S.: Evaluating the potential of high-resolution airborne $\mathrm{Li}-$ DAR data in glaciology, Int. J. Remote Sens., 27, 1233-1251, doi:10.1080/01431160500353817, 2006.

Aryal, A., Brooks, B. A., Reid, M. E., Bawden, G. W., and Pawlak, G. R.: Displacement fields from point cloud data: Application of particle imaging velocimetry to landslide geodesy, J. Geophys. Res.-Atmos., 117, F01029, doi:10.1029/2011JF002161, 2012.

Asner, G. P., Knapp, D. E., Boardman, J., Green, R. O., Kennedy-Bowdoin, T., Eastwood, M., Martin, R. E., Anderson, C., and Field, C. B.: Carnegie Airborne Observatory2: Increasing science data dimensionality via high-fidelity 
multi-sensor fusion, Remote Sens. Environ., 124, 454-465, doi:10.1016/j.rse.2012.06.012, 2012a.

Asner, G. P., Mascaro, J., Muller-Landau, H., Vieilledent, G., Vaudry, R., Rasamoelina, M., Hall, J., and van Breugel, M.: A universal airborne LiDAR approach for tropical forest carbon mapping, Oecologia, 168, 1147-1160, doi:10.1007/s00442-0112165-z, 2012b.

Avitabile, V., Baccini, A., Friedl, M. A., and Schmullius, C.: Capabilities and limitations of Landsat and land cover data for aboveground woody biomass estimation of Uganda, Remote Sens. Environ., 117, 366-380, doi:10.1016/j.rse.2011.10.012, 2012.

Baccini, A., Goetz, S. J., Walker, W. S., Laporte, N. T., Sun, M., Sulla-Menashe, D., Hackler, J., Beck, P. S. A., Dubayah, R., Friedl, M. A., Samanta, S., and Houghton, R. A.: Estimated carbon dioxide emissions from tropical deforestation improved by carbon-density maps, Nature Climate Change, 2, 182-185, doi:10.1038/nclimate1354, 2012.

Barnhart, T. B. and Crosby, B. T.: Comparing Two Methods of Surface Change Detection on an Evolving Thermokarst Using HighTemporal-Frequency Terrestrial Laser Scanning, Selawik River, Alaska, Remote Sens., 5, 2813-2837, doi:10.3390/rs5062813, 2013.

Bates, P. D.: Integrating remote sensing data with flood inundation models: how far have we got?, Hydrol. Process., 26, 2515-2521, doi:10.1002/hyp.9374, 2012.

Belmont, P., Gran, K. B., Schottler, S. P., Wilcock, P. R., Day, S. S., Jennings, C., Lauer, J. W., Viparelli, E., Willenbring, J. K., Engstrom, D. R., and Parker, G.: Large Shift in Source of Fine Sediment in the Upper Mississippi River, Environ. Sci. Technol., 45, 8804-8810, doi:10.1021/es2019109, 2011.

Bittner, S., Gayler, S., Biernath, C., Winkler, J. B., Seifert, S., Pretzsch, H. and Priesack, E.: Evaluation of a ray-tracing canopy light model based on terrestrial laser scans, Can. J. Remote Sens., 38, 619-628, doi:10.5589/m12-050, 2014.

Bode, C. A., Limm, M. P., Power, M. E., and Finlay, J. C.: Subcanopy Solar Radiation model: Predicting solar radiation across a heavily vegetated landscape using LiDAR and GIS solar radiation models, Remote Sens. Environ., 154, 387-397, doi:10.1016/j.rse.2014.01.028, 2014.

Booth, A. M., Roering, J. J., and Perron, J. T.: Automated landslide mapping using spectral analysis and highresolution topographic data: Puget Sound lowlands, Washington, and Portland Hills, Oregon, Geomorphology, 109, 132-147, doi:10.1016/j.geomorph.2009.02.027, 2009.

Bork, E. W. and Su, J. G.: Integrating LIDAR data and multispectral imagery for enhanced classification of rangeland vegetation: A meta analysis, Remote Sens. Environ., 111, 11-24, doi:10.1016/j.rse.2007.03.011, 2007.

Boutet, J. C., Jr and Weishampel, J. F.: Spatial pattern analysis of pre- and post-hurricane forest canopy structure in North Carolina, USA, Landscape Ecol., 18, 553-559, doi:10.1023/A:1026058312853, 2003.

Brasington, J., Vericat, D., and Rychkov, I.: Modeling river bed morphology, roughness, and surface sedimentology using high resolution terrestrial laser scanning, Water Resour. Res., 48, W11519, doi:10.1029/2012WR012223, 2012.

Bright, B. C., Hudak, A. T., McGaughey, R., Andersen, H.-E., and Negrón, J.: Predicting live and dead tree basal area of bark beetle affected forests from discrete-return lidar, Can. J. Remote Sens., 39, S99-S111, doi:10.5589/m13-027, 2014.

Brooks, B. A., Glennie, C., Hudnut, K. W., Ericksen, T., and Hauser, D.: Mobile Laser Scanning Applied to the Earth Sciences, Eos, Transactions American Geophysical Union, 94, 313 315, doi:10.1002/2013EO360002, 2013.

Broxton, P. D., Harpold, A. A., Brooks, P. D., Troch, P. A., and Molotch, N. P.: Quantifying the effects of vegetation structure on wintertime vapor losses from snow in mixed-conifer forests, Ecohydrol., doi:10.1002/eco.1565, in press, 2014.

Brubaker, K. M., Myers, W. L., Drohan, P. J., Miller, D. A., and Boyer, E. W.: The Use of LiDAR Terrain Data in Characterizing Surface Roughness and Microtopography, Appl. Environ. Soil Sci., 13, 891534, doi:10.1155/2013/891534, 2013.

Cho, M. A., Mathieu, R., Asner, G. P., Naidoo, L., van Aardt, J., Ramoelo, A., Debba, P., Wessels, K., Main, R., Smit, I. P. J., and Erasmus, B.: Mapping tree species composition in South African savannas using an integrated airborne spectral and LiDAR system, Remote Sens. Environ., 125, 214-226, doi:10.1016/j.rse.2012.07.010, 2012.

Chorover, J., Troch, P. A., Rasmussen, C., Brooks, P. D., Pelletier, J. D., Breshars, D. D., Huxman, T. E., Kurc, S. A., Lohse, K. A., McIntosh, J. C., Meixner, T., Schaap, M. G., Litvak, M. E., Perdrial, J., Harpold, A., and Durcik, M.: How Water, Carbon, and Energy Drive Critical Zone Evolution: The Jemez-Santa Catalina Critical Zone Observatory, Vadose Zone Journal, 10, 884-899, 2011.

Coops, N. C., Morsdorf, F., Schaepman, M. E., and Zimmermann, N. E.: Characterization of an alpine tree line using airborne LiDAR data and physiological modeling, Glob. Change Biol., 19, 3808-3821, doi:10.1111/gcb.12319, 2013.

Crosby, C., Arrowsmith, R., Nandigam, V., and Chaitanya, B, J. R. A. and Crosby et al, C. J.: Online access and processing of LiDAR topography data, Cambridge University Press, 251-265, 2011.

Day, S. S., Gran, K. B., Belmont, P., and Wawrzyniec, T.: Measuring bluff erosion part 1: terrestrial laser scanning methods for change detection, Earth Surf. Proc. Land., 38, 1055-1067, doi:10.1002/esp.3353, 2013.

Deems, J. S., Fassnacht, S. R., and Elder, K. J.: Fractal Distribution of Snow Depth from Lidar Data, J. Hydrometeor, 7, 285-297, doi:10.1175/JHM487.1, 2006.

Deems, J. S., Fassnacht, S. R., and Elder, K. J.: Interannual Consistency in Fractal Snow Depth Patterns at Two Colorado Mountain Sites, J. Hydrometeor, 9, 977-988, doi:10.1175/2008JHM901.1, 2008.

Deems, J. S., Painter, T. H., and Finnegan, D. C.: LiDAR measurement of snow depth: a review, J. Glaciol., 59, 467-479, doi:10.3189/2013JoG12J154, 2013.

DeLong, S. B., Prentice, C. S., Hilley, G. E., and Ebert, Y.: Multitemporal ALSM change detection, sediment delivery, and process mapping at an active earthflow, Earth Surf. Proc. Land., 37, 262-272, doi:10.1002/esp.2234, 2011.

Dickinson, Y., Zenner, E. K., and Miller, D.: Examining the effect of diverse management strategies on landscape scale patterns of forest structure in Pennsylvania using novel remote sensing techniques, Can. J. For. Res., 44, 301-312, doi:10.1139/cjfr-20130315, 2014. 
Drake, J. B. and Weishampel, J. F.: Multifractal analysis of canopy height measures in a longleaf pine savanna, Forest Ecol. Manage., 128, 121-127, doi:10.1016/S0378-1127(99)00279-0, 2000.

Egli, L., Jonas, T., Grünewald, T., Schirmer, M., and Burlando, P.: Dynamics of snow ablation in a small Alpine catchment observed by repeated terrestrial laser scans, Hydrol. Process., 26, 15741585, doi:10.1002/hyp.8244, 2011.

Essery, R., Bunting, P., Rowlands, A., Rutter, N., Hardy, J., Melloh, R., Link, T., Marks, D., and Pomeroy, J.: Radiative Transfer Modeling of a Coniferous Canopy Characterized by Airborne Remote Sens., J. Hydrometeor, 9, 228-241, doi:10.1175/2007JHM870.1, 2008.

Fassnacht, S. R. and Deems, J. S.: Measurement sampling and scaling for deep montane snow depth data, Hydrol. Process., 20, 829-838, doi:10.1002/hyp.6119, 2006.

Fernandez-Diaz, J. C., Glennie, C. L., Carter, W. E., Shrestha, R. L., Sartori, M. P., Singhania, A., Legleiter, C. J., and Overstreet, B. T.: Early Results of Simultaneous Terrain and Shallow Water Bathymetry Mapping Using a Single-Wavelength Airborne LiDAR Sensor, Selected Topics in Applied Earth Observations and Remote Sens., IEEE Geosci. Remote S., 7, 623-635, doi:10.1109/JSTARS.2013.2265255, 2014.

Fewtrell, T. J., Bates, P. D., Horritt, M., and Hunter, N. M.: Evaluating the effect of scale in flood inundation modelling in urban environments, Hydrol. Process., 22, 5107-5118, doi:10.1002/hyp.7148, 2008.

Féret, J.-B. and Asner, G. P.: Semi-Supervised Methods to Identify Individual Crowns of Lowland Tropical Canopy Species Using Imaging Spectroscopy and LiDAR, Remote Sens., 4, 2457-2476, doi:10.3390/rs4082457, 2012.

Flener, C., Vaaja, M., Jaakkola, A., Krooks, A., Kaartinen, H., Kukko, A., Kasvi, E., Hyyppä, H., Hyyppä, J. and Alho, P.: Seamless Mapping of River Channels at High Resolution Using Mobile LiDAR and UAV-Photography, Remote Sens., 5, 63826407, doi:10.3390/rs5126382, 2013.

Fonstad, M. A., Dietrich, J. T., Courville, B. C., Jensen, J. L., and Carbonneau P. E.: Topographic structure from motion: a new development in photogrammetric measurement, Earth Surf. Proc. Land., 38, 421-430, doi:10.1002/esp.3366, 2013.

Forzieri, G., Moser, G., Vivoni, E. R., Castelli, F. and Canovaro, F.: Riparian Vegetation Mapping for Hydraulic Roughness Estimation Using Very High Resolution Remote Sens. Data Fusion, J. Hydraul. Eng., 136, 855-867, doi:10.1061/(ASCE)HY.19437900.0000254, 2010.

Frazer, G. W., Wulder, M. A., and Niemann, K. O.: Simulation and quantification of the fine-scale spatial pattern and heterogeneity of forest canopy structure: A lacunarity-based method designed for analysis of continuous canopy heights, Forest Ecol. Manage., 214, 65-90, doi:10.1016/j.foreco.2005.03.056, 2005.

French, J. R.: Airborne LiDAR in support of geomorphological and hydraulic modelling, Earth Surf. Proc. Land., 28, 321-335, doi:10.1002/esp.484, 2003.

Glenn, N. F., Streutker, D. R., Chadwick, D. J., Thackray, G. D., and Dorsch, S. J.: Analysis of LiDAR-derived topographic information for characterizing and differentiating landslide morphology and activity, Geomorphology, 73, 131-148, doi:10.1016/j.geomorph.2005.07.006, 2006.
Glennie, C. L., Carter, W. E., Shrestha, R. L., and Dietrich, W. E.: Geodetic imaging with airborne LiDAR: the Earth's surface revealed, Rep. Prog. Phys., 76, 1-24, 2013.

Glennie, C. L., Hinojosa-Corona, A., Nissen, E., Kusari, A., Oskin, M. E., Arrowsmith, J. R., and Borsa, A.: Optimization of legacy lidar data sets for measuring near-field earthquake displacements, Geophys. Res. Lett., 41, 2014GL059919, doi:10.1002/2014GL059919, 2014.

Guzzetti, F., Mondini, A. C., Cardinali, M., Fiorucci, F., Santangelo, M., and Chang, K.-T.: Landslide inventory maps: New tools for an old problem, Earth Sci. Rev., 112, 42-66, doi:10.1002/2014GL059919, 2012.

Grünewald, T., Schirmer, M., Mott, R., and Lehning, M.: Spatial and temporal variability of snow depth and ablation rates in a small mountain catchment, The Cryosphere, 4, 215-225, doi:10.5194/tc-4-215-2010, 2010.

Hakala, T., Suomalainen, J., Kaasalainen, S., and Chen, Y.: Full waveform hyperspectral LiDAR for terrestrial laser scanning, Opt. Express, 20, 7119-7127, doi:10.1364/OE.20.007119, 2012.

Harman, C. J., Lohse, K. A., Troch, P. A., and Sivapalan, M.: Spatial patterns of vegetation, soils, and microtopography from terrestrial laser scanning on two semiarid hillslopes of contrasting lithology, J. Geophys. Res.-Biogeo., 119, 163-180, doi:10.1002/2013JG002507, 2014.

Harpold, A. A., Biederman, J. A., Condon, K., Merino, M., Korgaonkar, Y., Nan, T., Sloat, L. L., Ross, M., and Brooks, P. D.: Changes in snow accumulation and ablation following the Las Conchas Forest Fire, New Mexico, USA, Ecohydrol., 7, 440452, doi:10.1002/eco.1363, 2014a.

Harpold, A. A., Guo, Q., Molotch, N., Brooks, P. D., Bales, R., Fernandez-Diaz, J. C., Musselman, K. N., Swetnam, T. L., Kirchner, P., Meadows, M. W., Flanagan, J., and Lucas, R.: LiDAR?derived snowpack data sets from mixed conifer forests across the Western United States, Water Resour. Res., 50, 2749 2755, doi:10.1002/2013WR013935, 2014b.

Hartzell, P., Glennie, C., Biber, K., and Khan, S.: Application of multispectral LiDAR to automated virtual outcrop geology, ISPRS J. Photogramm., 88, 147-155, doi:10.1016/j.isprsjprs.2013.12.004, 2014.

Hedrick, A., Marshall, H.-P., Winstral, A., Elder, K., Yueh, S., and Cline, D.: Independent evaluation of the SNODAS snow depth product using regional-scale lidar-derived measurements, The Cryosphere, 9, 13-23, doi:10.5194/tc-9-13-2015, 2015.

Hopkinson, C. and Demuth, M. N.: Using airborne lidar to assess the influence of glacier downwasting on water resources in the Canadian Rocky Mountains, Can. J. Remote Sens., 32, 212-222, doi:10.5589/m06-012, 2006.

Hopkinson, C., Collins, T., Anderson, A., Pomeroy, J., and Spooner, I.: Spatial Snow Depth Assessment Using LiDAR Transect Samples and Public GIS Data Layers in the Elbow River Watershed, Alberta, Can. Water Resour. J., 37, 69-87, doi:10.4296/cwrj3702893, 2012.

Hopkinson, C., Lovell, J., Chasmer, L., Jupp, D., Kljun, N., and van Gorsel, E.: Integrating terrestrial and airborne lidar to calibrate a 3D canopy model of effective leaf area index, Remote Sens. Environ., 136, 301-314, doi:10.1016/j.rse.2013.05.012, 2013.

Hudak, A. T., Strand, E. K., Vierling, L. A., Byrne, J. C., Eitel, J. U. H., Martinuzzi, S., and Falkowski, M. J.: Quantifying aboveground forest carbon pools and fluxes from re- 
peat LiDAR surveys, Remote Sens. Environ., 123, 25-40, doi:10.1016/j.rse.2012.02.023, 2012.

Hurst, M. D., Mudd, S. M., Walcott, R., Attal, M., and Yoo, K.: Using hilltop curvature to derive the spatial distribution of erosion rates, J. Geophys. Res.-Atmos., 117, F02017, doi:10.1029/2011JF002057, 2012.

Hurst, M. D., Mudd, S. M., Yoo, K., Attal, M., and Walcott, R.: Influence of lithology on hillslope morphology and response to tectonic forcing in the northern Sierra Nevada of California, J. Geophys. Res.-Earth, 118, 832-851, doi::10.1002/jgrf.20049, 2013.

Hyde, P., Dubayah, R., Peterson, B., BLAIR, J., Hofton, M., Hunsaker, C., Knox, R., and Walker, W.: Mapping forest structure for wildlife habitat analysis using waveform lidar: Validation of montane ecosystems, Remote Sens. Environ., 96, 427-437, doi:10.1016/j.rse.2005.03.005, 2005.

Hyyppä, J., Holopainen, M., and Olsson, H.: Laser Scanning in Forests, Remote Sens., 4, 2919-2922, doi:10.3390/rs4102919, 2012

James, L. A., Singer, M. B., Ghoshal, S., and Megison, M.: Historical channel changes in the lower Yuba and Feather Rivers, California: Long-term effects of contrasting river-management strategies, in Management and Restoration of Fluvial Systems with Broad Historical Changes and Human Impacts, Geological Society of America, 451, 57-81, doi:10.1130/2009.2451(04), 2009

James, L. A., Hodgson, M. E., Ghoshal, S., and Latiolais, M. M.: Geomorphic change detection using historic maps and DEM differencing: The temporal dimension of geospatial analysis, Geomorphology, 137, 181-198, doi:10.1016/j.geomorph.2010.10.039, 2012.

James, M. R. and Robson, S.: Straightforward reconstruction of 3D surfaces and topography with a camera: Accuracy and geoscience application, J. Geophys. Res., 117, F03017, doi:10.1029/2011JF002289, 2010.

Javernick, L., Brasington, J., and Caruso, B.: Modeling the topography of shallow braided rivers using Structure-fromMotion photogrammetry, Geomorphology, 213, 166-182, doi:10.1016/j.geomorph.2014.01.006, 2014.

Jencso, K. G., McGlynn, B. L., Gooseff, M. N., Wondzell, S. M., Bencala, K. E., and Marshall, L. A.: Hydrologic connectivity between landscapes and streams: Transferring reach?and plot?scale understanding to the catchment scale, Water Resour. Res., 45, W04428, doi:10.1029/2008WR007225, 2009.

Jones, A. F., Brewer, P. A., Johnstone, E., and Macklin, M. G.: Highresolution interpretative geomorphological mapping of river valley environments using airborne LiDAR data, Earth Surf. Proc. Land., 32, 1574-1592, doi:10.1002/esp.1505, 2007.

Kaasalainen, S., Lindroos, T., and Hyyppä, J.: Toward Hyperspectral Lidar: Measurement of Spectral Backscatter Intensity With a Supercontinuum Laser Source, IEEE T. Geosci. Remote, 4, $211-$ 215, doi:10.1109/LGRS.2006.888848, 2007.

Kampe, T.U., Johnson, B. R., Kuester, M., and Keller, M.: NEON: the first continental-scale ecological observatory with airborne remote sensing of vegetation canopy biochemistry and structure, J. Appl. Remote Sens., 4, 043510-043510, doi:10.1117/1.3361375, 2010

Kessler, A. C., Gupta, S. C., Dolliver, H. A. S., and Thoma, D. P.: Lidar Quantification of Bank Erosion in Blue Earth County,
Minnesota, Journal of Environmental Quality, 41, 197-207, doi:10.2134/jeq2011.0181, 2012.

Kinzel, P. J., Wright, C. W., Nelson, J. M., and Burman, A. R.: Evaluation of an Experimental LiDAR for Surveying a Shallow, Braided, Sand-Bedded River, J. Hydraul. Eng., 133, 838-842, doi:10.1061/(ASCE)0733-9429(2007)133:7(838), 2007.

Kinzel, P. J., Legleiter, C. J., and Nelson, J. M.: Mapping River Bathymetry With a Small Footprint Green LiDAR: Applications and Challenges1, JAWRA J. Am. Water Resour. As., 49, 183204, doi:10.1111/jawr.12008, 2013.

Kirchner, P. B., Bales, R. C., Molotch, N. P., Flanagan, J., and Guo, Q.: LiDAR measurement of seasonal snow accumulation along an elevation gradient in the southern Sierra Nevada, California, Hydrol. Earth Syst. Sci. Discuss., 11, 5327-5365, doi:10.5194/hessd-11-5327-2014, 2014.

Kohler, J., Neumann, T. A., Robbins, J. W., Tronstad, S., and Melland, G.: ICESat Elevations in Antarctica Along the 2007-2009 Norway-USA Traverse: Validation With GroundBased GPS, IEEE T. Geosci. Remote, 51, 1578-1587, doi:10.1109/TGRS.2012.2207963, 2013.

Krishnan, S., Crosby, C., Nandigam, V., Phan, M., Cowart, C., Baru, C., and Arrowsmith, R.: OpenTopography: A Services Oriented Architecture for Community Access to LIDAR Topography, 7:17:8, ACM, New York, NY, USA, 2011.

Kurz, T. H., Buckley, S. J., Howell, J. A., and Schneider, D.: Integration of panoramic hyperspectral imaging with terrestrial lidar data, The Photogrammetric Record, 26, 212-228, doi:10.1111/j.1477-9730.2011.00632.x, 2011.

Lague, D., Brodu, N., and leroux, J.: Accurate 3D comparison of complex topography with terrestrial laser scanner: Application to the Rangitikei canyon (N-Z), ISPRS J. Photogramm., 82, 10 26, doi:10.1016/j.isprsjprs.2013.04.009, 2013.

Lam, N., Nathanson, M., Lundgren, N., Rehnström, R., and Lyon, S. W.: A Cost-Effective Laser Scanning Method for Mapping Stream Channel Geometry and Roughness, J. Am. Water Resour. As., 1-10, doi:10.1111/1752-1688.12299, 2015.

Lane, C. and D'Amico, E.: Calculating the Ecosystem Service of Water Storage in Isolated Wetlands using LiDAR in North Central Florida, USA, Wetlands, 30, 967-977, doi:10.1007/s13157010-0085-z, 2010.

Lane, S. N., Brookes, C. J., Kirkby, M. J., and Holden, J.: A network index based version of TOPMODEL for use with high resolution digital topographic data, Hydrol. Proces., 18, 191-201, doi:10.1002/hyp.5208, 2004.

Lee, H., Slatton, K. C., Roth, B. E., and Cropper, W. P.: Prediction of forest canopy light interception using three dimensional airborne LiDAR data, Int. J. Remote Sens., 30, 189-207, doi:10.1080/01431160802261171, 2009.

Lefsky, M. A., Cohen, W. B., Parker, G. G., and Harding, D. J.: Lidar Remote Sensing for Ecosystem Studies, BioScience, 52, 19-30, 2002.

Legleiter, C. J., Kyriakidis, P. C., McDonald, R. R., and Nelson, J. M.: Effects of uncertain topographic input data on twodimensional flow modeling in a gravel-bed river, Water Resour. Res., 47, W03518, doi:10.1029/2010WR009618, 2011.

Levy, J. S., Fountain, A. G., Dickson, J. L., Head, J. W., Okal, M., Marchant, D. R., and Watters, J.: Accelerated thermokarst formation in the McMurdo Dry Valleys, Antarctica, Sci. Rep., 3, 2269, doi:10.1038/srep02269, 2013. 
Li, S., MacMillan, R. A., Lobb, D. A., McConkey, B. G., Moulin, A., and Fraser, W. R.: Lidar DEM error analyses and topographic depression identification in a hummocky landscape in the prairie region of Canada, Geomorphology, 129, 263-275, doi:10.1016/j.geomorph.2011.02.020, 2011.

Lin, Y., Hyyppä, J., and Jaakkola, A.: Mini-UAV-Borne LIDAR for Fine-Scale Mapping, IEEE T. Geosci. Remote, 8, 426-430, doi:10.1109/LGRS.2010.2079913, 2011.

Lotsari, E., Vaaja, M., Flener, C., Kaartinen, H., Kukko, A., Kasvi, E., Hyyppä, H., Hyyppä, J., and Alho P.: Annual bank and point bar morphodynamics of a meandering river determined by highaccuracy multitemporal laser scanning and flow data, Water Resour. Res., 50, 5532-5559, doi:10.1002/2013WR014106, 2014.

Lyon, S. W., Nathanson, M., Lam, N., Dahlke, H. E., Rutzinger, M., Kean, J. W., and Laudon, H.: Can Low-Resolution Airborne Laser Scanning Data Be Used to Model Stream Rating Curves?, Water, 7, 1324-1339, doi:10.3390/w7041324, 2015.

Mallet, C. and Bretar, F.: Full-waveform topographic LiDAR: State-of-the-art, ISPRS J. Photogramm., 64, 1-16, doi:10.1016/j.isprsjprs.2008.09.007, 2009.

Maltamo, M., Næsset, E., and Vauhkonen, J. (Eds.): Forestry Applications of Airborne Laser Scanning, Springer, Netherlands, 269292, 2014

Mandlburger, G., Hauer, C., Höfle, B., Habersack, H., and Pfeifer, N.: Optimisation of LiDAR derived terrain models for river flow modelling, Hydrol. Earth Syst. Sci., 13, 1453-1466, doi:10.5194/hess-13-1453-2009, 2009.

Mankoff, K. D. and Russo, T. A.: The Kinect: a low-cost, highresolution, short-range 3D camera, Earth Surf. Proc. Land., 38, 926-936, doi:10.1002/esp.3332, 2013.

Marks, K. and Bates, P.: Integration of high-resolution topographic data with floodplain flow models, Hydrol. Process., 14, 2109-2122, doi:10.1002/10991085(20000815/30)14:11/12<2109::AID-HYP58>3.0.CO;2-1, 2000.

Marshall, J. A. and Roering, J. J.: Diagenetic variation in the Oregon Coast Range: Implications for rock strength, soil production, hillslope form, and landscape evolution, J. Geophys. Res.-Earth, 119, 2013JF003004, doi:10.1002/2013JF003004, 2014.

Martinuzzi, S., Vierling, L. A., Gould, W. A., Falkowski, M. J., Evans, J. S., Hudak, A. T., and Vierling, K. T.: Mapping snags and understory shrubs for a LiDAR-based assessment of wildlife habitat suitability, Remote Sens. Environ., 113, 25332546, doi:10.1016/j.rse.2009.07.002, 2009

Mascaro, J., Detto, M., Asner, G. P., and Muller-Landau, H. C.: Evaluating uncertainty in mapping forest carbon with airborne LiDAR, Remote Sens. Environ., 115, 3770-3774, doi:10.1016/j.rse.2011.07.019, 2011.

Mason, D. C., Cobby, D. M., Horritt, M. S., and Bates, P. D.: Floodplain friction parameterization in two-dimensional river flood models using vegetation heights derived from airborne scanning laser altimetry, Hydrol. Process., 17, 1711-1732, doi:10.1002/hyp.1270, 2003.

Mattmann, C. A.: Computing: A vision for data science, Nature, 493, 473-475, doi:10.1038/493473a, 2013.

McCreight, J. L., Slater, A. G., Marshall, H. P., and Rajagopalan, B.: Inference and uncertainty of snow depth spatial distribution at the kilometre scale in the Colorado Rocky Mountains: the effects of sample size, random sampling, predictor qual- ity, and validation procedures, Hydrol. Process., 28, 933-957, doi:10.1002/hyp.9618, 2014.

McKean, J., Isaak, D., and Wright, W.: Improving Stream Studies With a Small-Footprint Green Lidar, Eos, Transactions American Geophysical Union, 90, 341-342, doi:10.1029/2009EO390002, 2009.

McKean, J., McKean, J., Tonina, D., Tonina, D., Bohn, C., Bohn, C., Wright, C. W., and Wright, C. W.: Effects of bathymetric lidar errors on flow properties predicted with a multidimensional hydraulic model, J. Geophys. Res.-Earth, 119, 644664, doi:10.1002/2013JF002897, 2014.

McKean, J. A., Isaak, D. J., and Wright, C. W.: Geomorphic controls on salmon nesting patterns described by a new, narrowbeam terrestrial-aquatic lidar, Front. Ecol. Environ., 6, 125-130, doi:10.1890/070109, 2008.

Meyer, V., Saatchi, S. S., Chave, J., Dalling, J. W., Bohlman, S., Fricker, G. A., Robinson, C., Neumann, M., and Hubbell, S.: Detecting tropical forest biomass dynamics from repeated airborne lidar measurements, Biogeosciences, 10, 5421-5438, doi:10.5194/bg-10-5421-2013, 2013.

Mitchell, P. J., Lane, P. N. J., and Benyon, R. G.: Capturing within catchment variation in evapotranspiration from montane forests using LiDAR canopy profiles with measured and modelled fluxes of water, Ecohydrol., 5, 708-720, doi:10.1002/eco.255, 2011.

Moeser, D., Roubinek, J., Schleppi, P., Morsdorf, F., and Jonas, T.: Canopy closure, LAI and radiation transfer from airborne LiDAR synthetic images, Agr. Forest Meteorol., 197, 158-168, doi:10.1016/j.agrformet.2014.06.008, 2014.

Mora, B., Wulder, M. A., Hobart, G. W., White, J. C., Bater, C. W., Gougeon, F. A., Varhola, A., and Coops, N. C.: Forest inventory stand height estimates from very high spatial resolution satellite imagery calibrated with lidar plots, Int. J. Remote Sens., 34, 4406-4424, doi:10.1080/01431161.2013.779041, 2013.

Mundt, J. T., Streutker, D. R., and Glenn, N. F.: Mapping Sagebrush Distribution Using Fusion of Hyperspectral and Lidar Classifications, Photogramm. Eng. Rem. S., 72, 47-54, doi:10.14358/PERS.72.1.47, 2006.

Musselman, K. N., Margulis, S. A., and Molotch, N. P.: Estimation of solar direct beam transmittance of conifer canopies from airborne LiDAR, Remote Sens. Environ., 136, 402-415, doi:10.1016/j.rse.2013.05.021, 2013.

Næsset, E. and Gobakken, T.: Estimating forest growth using canopy metrics derived from airborne laser scanner data, Remote Sens. Environ., 96, 453-465, doi:10.1016/j.rse.2005.04.001, 2005.

Nathanson, M., Kean, J. W., Grabs, T. J., Seibert, J., Laudon, H., and Lyon, S. W.: Modelling rating curves using remotely sensed LiDAR data, Hydrol. Process., 26, 1427-1434, doi:10.1002/hyp.9225, 2012.

National Research Council: New Research Opportunities in the Earth Sciences, National Academy Press, Washington D.C., ailable at: http://www.nap.edu/openbook.php?record_id=13236 (last access 31 October 2014), 2012.

Nissen, E., Krishnan, A. K., Arrowsmith, J. R., and Saripalli, S.: Three-dimensional surface displacements and rotations from differencing pre- and post-earthquake LiDAR point clouds, Geophys. Res. Lett., 39, L16301, doi:10.1029/2012GL052460, 2012.

Nissen, E., Maruyama, T., Arrowsmith, J. R., Elliott, J. R., Krishnan, A. K., Oskin, M. E., and Saripalli, S.: Coseismic fault 
zone deformation revealed with differential lidar: examples from Japanese Mw 7 intraplate earthquakes, Earth Planet. Sci. Lett., 405, 244-256, doi:10.1016/j.eps1.2014.08.031, 2014.

Olsoy, P. J., Glenn, N. F., Clark, P. E., and Derryberry, D. R.: Aboveground total and green biomass of dryland shrub derived from terrestrial laser scanning, ISPRS J. Photogramm., 88, 166-173, doi:10.1016/j.isprsjprs.2013.12.006, 2014.

Oskin, M. E., Arrowsmith, J. R., Corona, A. H., Elliott, A. J., Fletcher, J. M., Fielding, E. J., Gold, P. O., Garcia, J. J. G., Hudnut, K. W., Liu-Zeng, J., and Teran, O. J.: Near-Field Deformation from the El Mayor-Cucapah Earthquake Revealed by Differential LIDAR, Science, 335, 702-705, doi:10.1126/science.1213778, 2012.

Palminteri, S., Powell, G. V. N., Asner, G. P., and Peres, C. A.: LiDAR measurements of canopy structure predict spatial distribution of a tropical mature forest primate, Remote Sens. Environ., 127, 98-105, doi:10.1016/j.rse.2012.08.014, 2012.

Passalacqua, P., Tarolli, P., and Foufoula-Georgiou, E.: Testing space-scale methodologies for automatic geomorphic feature extraction from lidar in a complex mountainous landscape, Water Resour. Res., 46, W11535, doi:10.1029/2009WR008812, 2010.

Pelletier, J. D.: Deviations from self-similarity in barchan form and flux: The case of the Salton Sea dunes, California, J. Geophys. Res.-Earth, 118, 2013JF002867, doi:10.1002/2013JF002867, 2013.

Pelletier, J. D. and Perron, J. T.: Analytic solution for the morphology of a soil-mantled valley undergoing steady headward growth: Validation using case studies in southeastern Arizona, J. Geophys. Res.-Earth, 117, F02018, doi:10.1029/2011JF002281, 2012.

Pelletier, J. D. and Orem, C. A.: How do sediment yields from postwildfire debris-laden flows depend on terrain slope, soil burn severity class, and drainage basin area? Insights from airborneLiDAR change detection, Earth Surf. Proc. Land., 39, 18221832, doi:10.1002/esp.3570, 2014.

Pelletier, J. D., DeLong, S. B., Orem, C. A., Becerra, P., Compton, K., Gressett, K., Lyons-Baral, J., McGuire, L. A., Molaro, J. L., and Spinler, J. C.: How do vegetation bands form in dry lands? Insights from numerical modeling and field studies in southern Nevada, USA, J. Geophys. Res.-Atmos., 117, F04026, doi:10.1029/2012JF002465, 2012.

Pelletier, J. D., Barron-Gafford, G. A., Breshears, D. D., Brooks, P. D., Chorover, J., Durcik, M., Harman, C. J., Huxman, T. E., Lohse, K. A., Lybrand, R., Meixner, T., McIntosh, J. C., Papuga, S. A., Rasmussen, C., Schaap, M., Swetnam, T. L., and Troch, P. A.: Coevolution of nonlinear trends in vegetation, soils, and topography with elevation and slope aspect: A case study in the sky islands of southern Arizona, J. Geophys. Res.-Earth, 118, 741-758, doi:10.1002/jgrf.20046, 2013.

Perignon, M. C., Tucker, G. E., Griffin, E. R., and Friedman, J. M.: Effects of riparian vegetation on topographic change during a large flood event, Rio Puerco, New Mexico, USA, J. Geophys. Res.-Earth, 118, 1193-1209, doi:10.1002/jgrf.20073, 2013.

Perron, J. T. and Hamon, J. L.: Equilibrium form of horizontally retreating, soil-mantled hillslopes: Model development and application to a groundwater sapping landscape, J. Geophys. Res.Atmos., 117, F01027, doi:10.1029/2011JF002139, 2012.

Perron, J. T., Kirchner, J. W., and Dietrich, W. E.: Spectral signatures of characteristic spatial scales and nonfractal struc- ture in landscapes, J. Geophys. Res.-Atmos., 113, F04003, doi:10.1029/2007JF000866, 2008.

Persson, A., Hasan, A., Tang, J., and Pilesjö, P.: Modelling Flow Routing in Permafrost Landscapes with TWI: An Evaluation against Site-Specific Wetness Measurements, Transactions in GIS, 16, 701-713, doi:10.1111/j.1467-9671.2012.01338.x, 2012.

Plotnick, R., Gardner, R., Hargrove, W., Prestegaard, K., and Perlmutter, M.: Lacunarity analysis: A general technique for the analysis of spatial patterns, Phys. Rev. E, 53, 5461-5468, doi:10.1103/PhysRevE.53.5461, 1996.

Rengers, F. K. and Tucker, G. E.: Analysis and modeling of gully headcut dynamics, North American high plains, J. Geophys. Res.-Earth, 119, 983-1003, doi:10.1002/2013JF002962, 2014.

Rhoades, E. L., O’Neal, M. A., and Pizzuto, J. E.: Quantifying bank erosion on the South River from 1937 to 2005, and its importance in assessing Hg contamination, Appl. Geogr., 29, 125-134, doi:10.1016/j.apgeog.2008.08.005, 2009.

Riaño, D., Valladares, F., Condés, S., and Chuvieco, E.: Estimation of leaf area index and covered ground from airborne laser scanner (Lidar) in two contrasting forests, Agr. Forest Meteorol., 124, 269-275, doi:10.1016/j.agrformet.2004.02.005, 2004

Richardson, J. J., Moskal, L. M., and Kim, S.-H.: Modeling approaches to estimate effective leaf area index from aerial discrete-return LIDAR, Agr. Forest Meteorol., 149, 1152-1160, doi:10.1016/j.agrformet.2009.02.007, 2009.

Roering, J. J.: How well can hillslope evolution models "explain" topography? Simulating soil transport and production with highresolution topographic data, Geol. Soc. Am. Bull., 120, 12481262, doi:10.1130/B26283.1, 2008.

Roering, J. J., Stimely, L. L., Mackey, B. H., and Schmidt, D. A.: Using DInSAR, airborne LiDAR, and archival air photos to quantify landsliding and sediment transport, Geophys. Res. Lett., 36, L19402, doi:10.1029/2009GL040374, 2009.

Roering, J. J., Marshall, J., Booth, A. M., Mort, M., and Jin, Q.: Evidence for biotic controls on topography and soil production, Earth Planet. Sci. Lett., 298, 183-190, doi:10.1016/j.epsl.2010.07.040, 2010.

Roering, J. J., Mackey, B. H., Marshall, J. A., Sweeney, K. E., Deligne, N. I., Booth, A. M., Handwerger, A. L., and CerovskiDarriau, C.: "You are HERE": Connecting the dots with airborne lidar for geomorphic fieldwork, Geomorphology, 200, 172-183, doi:10.1016/j.geomorph.2013.04.009, 2013.

Sankey, J. B., Glenn, N. F., Germino, M. J., Gironella, A. I. N., and Thackray, G. D.: Relationships of aeolian erosion and deposition with LiDAR-derived landscape surface roughness following wildfire, Geomorphology, 119, 135-145, doi:10.1016/j.geomorph.2010.03.013, 2010.

Sankey, J. B., Law, D. J., Breshears, D. D., Munson, S. M., and Webb, R. H.: Employing lidar to detail vegetation canopy architecture for prediction of aeolian transport, Geophys. Res. Lett., 40, 1724-1728, doi:10.1002/grl.50356, 2013.

Schimel, D. S., Asner, G. P., and Moorcroft, P.: Observing changing ecological diversity in the Anthropocene, Front. Ecol. Environ., 11, 129-137, doi:10.1890/120111, 2013.

Seidel, D., Fleck, S., Leuschner, C., and Hammett, T.: Review of ground-based methods to measure the distribution of biomass in forest canopies, Ann. For. Sci., 68, 225-244, doi:10.1007/s13595-011-0040-z, 2011. 
Shook, K., Pomeroy, J. W., Spence, C., and Boychuk, L.: Storage dynamics simulations in prairie wetland hydrology models: evaluation and parameterization, Hydrol. Process., 27, 1875-1889, doi:10.1002/hyp.9867, 2013.

Simard, M., Pinto, N., Fisher, J. B., and Baccini, A.: Mapping forest canopy height globally with spaceborne lidar, J. Geophys. Res.Atmos., 116, G04021, doi:10.1029/2011JG001708, 2011.

Snyder, N. P.: Studying Stream Morphology With Airborne Laser Elevation Data, Eos, Transactions American Geophysical Union, 90, 45-46, doi:10.1029/2009EO060001, 2009.

Sørensen, R. and Seibert, J.: Effects of DEM resolution on the calculation of topographical indices: TWI and its components, J. Hydrol., 347, 79-89, doi:10.1016/j.jhydrol.2007.09.001, 2007.

Staley, D. M., Wasklewicz, T. A., and Kean, J. W.: Characterizing the primary material sources and dominant erosional processes for post-fire debris-flow initiation in a headwater basin using multi-temporal terrestrial laser scanning data, Geomorphology, 214, 324-338, doi:10.1016/j.geomorph.2014.02.015, 2014.

Stennett, T. A.: Lidar: Strap in tight, and prepare to go vertical, Photogramm. Eng. Rem. S., 70, 545-548, 2004.

Stout, J. C. and Belmont, P.: TerEx Toolbox for semi-automated selection of fluvial terrace and floodplain features from lidar, Earth Surf. Proc. Land., 39, 569-580, doi:10.1002/esp.3464, 2014.

Streutker, D. R. and Glenn, N. F.: LiDAR measurement of sagebrush steppe vegetation heights, Remote Sens. Environ., 102, 135-145, doi:10.1016/j.rse.2006.02.011, 2006.

Tarolli, P.: High-resolution topography for understanding Earth surface processes: Opportunities and challenges, Geomorphology, 216, 295-312, doi:10.1016/j.geomorph.2014.03.008, 2014.

Tenenbaum, D. E., Band, L. E., Kenworthy, S. T., and Tague, C. L.: Analysis of soil moisture patterns in forested and suburban catchments in Baltimore, Maryland, using high-resolution photogrammetric and LIDAR digital elevation datasets, Hydrol. Process., 20, 219-240, doi:10.1002/hyp.5895, 2006.

Thoma, D. P., Gupta, S. C., Bauer, M. E., and Kirchoff, C. E.: Airborne laser scanning for riverbank erosion assessment, Remote Sens. Environ., 95, 493-501, doi:10.1016/j.rse.2005.01.012, 2005.

Tinkham, W. T., Smith, A. M. S., Marshall, H.-P., Link, T. E., Falkowski, M. J., and Winstral, A. H.: Quantifying spatial distribution of snow depth errors from LiDAR using Random Forest, Remote Sens. Environ., 141, 105-115, doi:10.1016/j.rse.2013.10.021, 2014.

Trujillo, E., Ramírez, J. A., and Elder, K. J.: Scaling properties and spatial organization of snow depth fields in sub-alpine forest and alpine tundra, Hydrol. Process., 23, 1575-1590, doi:10.1002/hyp.7270, 2009.

Varhola, A. and Coops, N. C.: Estimation of watershed-level distributed forest structure metrics relevant to hydrologic modeling using LiDAR and Landsat, J. Hydrol., 487, 70-86, doi:10.1016/j.jhydrol.2013.02.032, 2013.

Varhola, A., Coops, N. C., Alila, Y., and Weiler, M.: Exploration of remotely sensed forest structure and ultrasonic range sensor metrics to improve empirical snow models, Hydrol. Process., 28, 4433-4448, doi:10.1002/hyp.9952, 2014.

Vierling, K. T., Vierling, L. A., Gould, W. A., Martinuzzi, S., and Clawges, R. M.: Lidar: shedding new light on habitat characterization and modeling, Front. Ecol. Environ., 6, 90-98, doi:10.1890/070001, 2008.
Vosselman, G. and Maas, H.-G.: Airborne and terrestrial laser scanning, CRC Press, London, 213-235, 2010.

Wagner, W., Hollaus, M., Briese, C., and Ducic, V.: 3D vegetation mapping using small footprint full?waveform airborne laser scanners, Int. J. Remote Sens., 29, 1433-1452, doi:10.1080/01431160701736398, 2008.

Wallace, L., Lucieer, A., Watson, C., and Turner, D.: Development of a UAV-LiDAR System with Application to Forest Inventory, Remote Sens., 4, 1519-1543, doi:10.3390/rs4061519, 2012.

Wedding, L. M., Friedlander, A. M., McGranaghan, M., Yost, R. S., and Monaco, M. E.: Using bathymetric lidar to define nearshore benthic habitat complexity: Implications for management of reef fish assemblages in Hawaii, Remote Sens. Environ., 112, 41594165, doi:10.1016/j.rse.2008.01.025, 2008.

West, N., Kirby, E., Bierman, P., and Clarke, B. A.: Aspectdependent variations in regolith creep revealed by meteoric 10Be, Geology, 42, 507-510, doi:10.1130/G35357.1, 2014.

Westoby, M. J., Brasington, J., Glasser, N. F., Hambrey, M. J., and Reynolds, J. M.: "Structure-from-Motion" photogrammetry: A low-cost, effective tool for geoscience applications, Geomorphology, 179, 300-314, doi:10.1016/j.geomorph.2012.08.021, 2012.

Wheaton, J. M., Brasington, J., Darby, S. E., and Sear, D. A.: Accounting for uncertainty in DEMs from repeat topographic surveys: improved sediment budgets, Earth Surf. Proc. Land., 35, 136-156, doi:10.1002/esp.1886, 2010a.

Wheaton, J. M., Brasington, J., Darby, S. E., Merz, J., Pasternack, G. B., Sear, D., and Vericat, D.: Linking geomorphic changes to salmonid habitat at a scale relevant to fish, River Res. Applic., 26, 469-486, doi:10.1002/rra.1305, 2010b.

Williams, G. D., Maksym, T., Kunz, C., Kimball, P., Singh, H., Wilkinson, J., Lachlan-Cope, T., Trujillo, E., Steer, A., Massom, R., Meiners, K., Heil, P., Lieser, J., and Leonard, K.: Beyond Point Measurements: Sea Ice Floes Characterized in 3D, Eos, Transactions American Geophysical Union, 94, 69-70, doi:10.1002/2013EO070002, 2013.

Wulder, M. A., White, J. C., Nelson, R. F., Næsset, E., Ørka, H. O., Coops, N. C., Hilker, T., Bater, C. W., and Gobakken, T.: Lidar sampling for large-area forest characterization: A review, Remote Sens. Environ., 121, 196-209, doi:10.1016/j.rse.2012.02.001, 2012.

Young, A. P., Olsen, M. J., Driscoll, N., Flick, R. E., Gutierrez, R., Guza, R. T., Johnstone, E., and Kuester, F.: Comparison of Airborne and Terrestrial Lidar Estimates of Seacliff Erosion in Southern California, Photogramm. Eng. Rem. S., 76, 421-427, doi:10.14358/PERS.76.4.421, 2010.

Yu, X., Hyyppä, J., Kaartinen, H., and Maltamo, M.: Automatic detection of harvested trees and determination of forest growth using airborne laser scanning, Remote Sens. Environ., 90, 451-462, doi:10.1016/j.rse.2004.02.001, 2004.

Zellweger, F., Morsdorf, F., Purves, R., Braunisch, V., and Bollmann, K.: Improved methods for measuring forest landscape structure: LiDAR complements field-based habitat assessment, Biodivers. Conserv., 23, 289-307, doi:10.1007/s10531-0130600-7, 2014.

Zhao, K., Popescu, S., and Nelson, R.: Lidar remote sensing of forest biomass: A scale-invariant estimation approach using airborne lasers, Remote Sens. Environ., 113, 182-196, doi:10.1016/j.rse.2008.09.009, 2009. 